\author{
MONIKA BIELIŃSKA \\ Uniwersytet Śląski w Katowicach \\ ORCID 0000-0003-3450-113X
}

\title{
Status i istota leksykografii. Stanowiska i kontrowersje
}

\section{Wprowadzenie}

Na pytanie, co to jest leksykografia, nie ma jednej odpowiedzi, o czym świadczą hasła w słownikach ogólnych i specjalistycznych, podręczniki do leksykografii i prace naukowe. Zróżnicowanie stanowisk jest tak duże, że samo stało się przedmiotem rozważań. Problem określenia natury i statusu leksykografii podejmowany jest w dyskusjach naukowych już od lat 60 . XX w. Nie sposób przytoczyć tu wszystkich prac z ostatniego półwiecza, ale warto podać kilka przykładów: Burkhard Schaeder (1987: 108-128), Władysław Miodunka (1989: 9-24, 53-58), Mirosław Bańko (2001: 10-24), Tadeusz Piotrowski (2001: 18-32), Werner Wolski (2005), Sven Tarp (2008: 4-13; 2010), Piotr Żmigrodzki (2008: 15-24), Henning Bergenholtz i Rufus Gouws (2012). W wymienionych publikacjach omawiane są rozbieżności w rozumieniu pojęcia leksykografii, część z nich zawiera skomentowane zestawienia definicji ze starszych i nowszych słowników, głównie ogólnych, leksykonów językoznawczych czy artykułów i monografii naukowych. Na szczególną uwagę zasługują prace Herberta Ernsta Wieganda (1989, 1998, 2013), który tą kwestią zajmuje się bardzo szczegółowo. W celu zbadania statusu leksykografii językowej pod koniec lat 90. XX w. i jej stosunku do innych dyscyplin przeanalizował ponad 150 tekstów na ten temat w języku niemieckim, angielskim, francuskim i hiszpańskim, gromadząc przy tym ponad czterdzieści różnych opinii (por. Wiegand 1998: 13-133; 2013: 16).

Warto jednak po raz kolejny poświęcić uwagę temu zagadnieniu. Literatura przedmiotu i słowniki dostarczają różnych, często całkowicie przeciwstawnych odpowiedzi na pytania: Czy leksykografia to praktyka/rzemiosło, teoria/nauka, czy też jedno i drugie? Czy leksykografia to dział językoznawstwa (stosowanego)? Gałąź leksykologii? Leksykologia stosowana? Dziedzina badań filologicznych i historycznych? Część informatologii? Samodzielna dyscyplina? Interesujące jest zbadanie przyczyn tych rozbieżności i przeanalizowanie argumentów przemawiających za sformułowaniem odpowiedzi 
twierdzących lub przeczących. Ponadto w wielu publikacjach, zarówno omawiających różne stanowiska, jak i po prostu przypisujących leksykografii określone cechy lub określony status uznany przez autora za niepodlegający dyskusji, daje się zaobserwować pewne zawężenie perspektywy, zwykle dwojakiego rodzaju. Z jednej strony rozważania ograniczają się do leksykografii językowej, z drugiej zaś bardzo pobieżnie traktowana jest w nich teoria leksykograficzna, czasem nawet uważana jest za teorię językoznawczą bądź opartą w znacznej mierze na językoznawstwie. Koncentrację na leksykografii językowej łatwo jest wytłumaczyć tym, że autorzy wspomnianych publikacji są językoznawcami, zainteresowanymi, co oczywiste, słownikami opisującymi język. Częstą konsekwencją takiego podejścia jest pomijanie aspektów niezależnych od przedmiotu opisu leksykograficznego, a stanowiących trzon leksykografii.

W kwestiach szczegółowych koncentracja na wybranych aspektach jest konieczna i uzasadniona. Jednakże w dyskusji na temat tak podstawowy i ogólny właściwsze wydaje się całościowe i wielostronne potraktowanie obiektu badań. Oznacza to uwzględnienie także leksykografii encyklopedycznej. Uznanie tej gałęzi leksykografii za „odrębne zagadnienie" (Miodunka 1989: 217) jest zrozumiałe, jeśli przedmiot opisu leksykograficznego jest istotny dla wyników badań. Gdy chodzi o status leksykografii, to różnice w samym przedmiocie opisu - język czy rzeczywistość pozajęzykowa - nie są sprawą konstytutywną. Decydująca jest baza leksykograficzna, wspólna dla publikacji leksykograficznych wszelkiego rodzaju. $Z$ tego powodu także terminografia nie powinna być wyłączana z takich rozważań (por. Bergenholtz 1995; Bergenholtz, Kaufmann 1997). Należy więc odrzucić stanowisko terminologów, którzy nie uważają terminografii za część leksykografii.

Ogólnym celem wywodu jest przedyskutowanie stanowisk na temat natury i statusu leksykografii z wyżej przedstawionej perspektywy. Dobór zagadnień podyktowany jest tym, co jest najszerzej omawiane w literaturze przedmiotu. Kolejne części poświęcone są zatem praktycznemu i teoretycznemu wymiarowi leksykografii (pkt 2), stosunkowi leksykografii do językoznawstwa, ze szczególnym uwzględnieniem leksykologii (pkt 3) oraz stanowisku, że leksykografia jest odrębną dyscypliną (pkt 4). Apendyks (pkt 7) zawiera definicje ze słowników i leksykonów omawiane w ramach poniższego przeglądu.

\section{Leksykografia jako praktyka i teoria}

Lista znaczeń przypisywanych terminowi leksykografia obejmuje trzy pozycje, które można, uogólniając, przedstawić następująco:

- opracowywanie słowników,

- nauka o słownikach

oraz

- ogół słowników danego języka, kraju, danej epoki czy dziedziny.

To ostatnie znaczenie nie będzie przedmiotem dalszych rozważań, skupiających się jedynie na praktycznym i teoretycznym aspekcie leksykografii.

W kwestii, czy leksykografia obejmuje zarówno tworzenie słowników, jak i pracę o charakterze teoretycznym, naukowym, zdania są podzielone. Wśród słowników 
ogólnych języka niemieckiego jedynie publikacje dziewiętnastowieczne definiują leksykografię wyłącznie jako praktykę. B. Schaeder (1987: 108) podaje tylko trzy takie przykłady. Trzeba przy tym zaznaczyć, że w większości słowników z tamtego okresu słowo „leksykografia” jeszcze nie występuje. Nowsze słowniki podają oba znaczenia, np. Ullstein-LdS, DUW1983, DUW2003, D6 i D10, ale niektóre traktują leksykografię tylko jako naukę, np. Wahrig, WDG czy HDG, mimo iż leksykograf jest według definicji zawartych w dwóch pierwszych słownikach (w HDG nie ma takiego hasła) osobą opracowującą słowniki, czyli praktykiem (por. analizę haseł w Schaeder 1987: 108-116). O ile zmiana w postrzeganiu leksykografii - najpierw sama praktyka, a potem także teoria - jest zrozumiała, gdyż refleksja teoretyczna i prace naukowe z dziedziny leksykografii pojawiły się później niż słowniki, trudno wyjaśnić pominięcie w niektórych definicjach komponentu praktycznego, bez którego nie powstałby przecież żaden słownik. Pod tym względem całkowicie odmienne są słowniki języka angielskiego. ODE, CALDT, COBUILD, Collins, Webster, LDOCE czy OEDShort określają leksykografię wyłącznie jako praktykę (activity / occupation / job / profession etc. of writing dictionaries). Współczesne słowniki języka polskiego uwzględniają zwykle oba komponenty, np. SJPDor, SJPSz ${ }^{1}$, WSJP, USJP. Niektóre ograniczają się do jednego i jest to wtedy komponent praktyczny. Dotyczy to nie tylko słowników starszych, np. słownika wileńskiego (1861) czy słownika Arcta (1929), ale też nowego ISJP (2000).

Leksykony z zakresu językoznawstwa traktują omawianą tu kwestię także niejednolicie. Przykładowo autorzy haseł w niemieckich leksykonach BLS i MLS uważają, że leksykografia to praktyka. Polskie publikacje EJP, EJO czy SDJO przypisują leksykografii wymiar praktyczny i naukowy, przy czym jedynie EJO nie sprowadza teorii do problemów związanych z opracowywaniem słowników i zalicza do zakresu badawczego także ,typologię słowników, teorię słownika jako formy przedstawienia materiału jęz. lub przedmiotowego, jako wytworu określonej kultury oraz jako środka kształtowania kultury społecznej” (Lewicki 1999: 331). Wyłącznie jako naukę postrzega leksykografię Ttt, który ponadto redukuje jej obszar w sposób dość specyficzny - nie do teorii związanej z opracowywaniem słowników (co też jest niewłaściwą, ale typową i łatwo wytłumaczalną redukcją), lecz do badania słowników w aspekcie typologicznym.

Leksykony z zakresu leksykografii ${ }^{2}$ : DoL, NLO i LDBT jednomyślnie reprezentują pogląd, że leksykografia obejmuje komponent praktyczny i teoretyczny.

Wśród artykułów i monografii nie ma chyba takich, które z zakresu leksykografii wykluczałyby praktykę, jak to czynią, co jest dość zaskakujące, niektóre słowniki, czyli produkty tej praktyki (por. wyżej). Stanowiska reprezentowane w pracach naukowych dają się podzielić na dwie grupy. Część autorów uważa leksykografię jedynie za działalność praktyczną, inni przypisują jej także wymiar teoretyczny.

Do zwolenników poglądu o wyłącznie praktycznym charakterze leksykografii należą m.in. Sue Atkins i Michael Rundell, którzy we wstępie do swojej książki piszą:

\footnotetext{
${ }^{1}$ Hasło z elektronicznej wersji Słownika języka polskiego PWN (2004) jest identyczne jak to w SJPSz.

2 WLWF nie został uwzględniony, gdyż dwa pierwsze tomy, które ukazały się do tej pory, nie obejmują odcinka „l”.
} 
„This is not a book about 'theoretical lexicography' - for the very good reason that we do not believe that such a thing exists" (Atkins, Rundell 2008: 4). Podobnie wypowiadają się Henri Béjoint (2010: 381): „I simply do not believe that there exists a theory of lexicography, and I very much doubt that there can be one" i Anna Wierzbicka (1985: 5): „lexicography has no theoretical foundation [...]”. Takie stanowiska S. Tarp podsumowuje jako ,a sort of capitulation to the theoretical problems and challenges facing modern lexicography" (Tarp 2010: 453).

W pracach definiujących leksykografię jako praktykę i teorię zwraca uwagę różnorodność podejść do komponentu teoretycznego. Część autorów traktuje teorię jedynie jako naukową podstawę opracowywania słowników. W. Miodunka (1989: 13) przedstawia teoretyczny wymiar leksykografii jako „odnoszący się do metod i technik opracowywania słowników". Leksykografię jako praktykę tworzenia słowników oraz teorię tejże praktyki ujmują także Helmut Henne (1980: 779), B. Schaeder (1981: 55) i Thea Schippan (1984: 47). Nierzadkie jest również częściowe bądź całkowite utożsamianie teorii leksykograficznej z teorią językoznawczą, por. Jan Czochralski (1981: 167), Günter Kempcke (1982: 44).

Odrębną podgrupę stanowią prace, w których rozwija się teorię leksykograficzną i pojmuje ją znacznie szerzej niż jako teoretyczną podstawę praktyki. Na pierwszym miejscu można wymienić prace H.E. Wieganda (np. 1998), wywierające ogromny wpływ na rozwój teorii leksykograficznej. Należy zwrócić uwagę na fakt, że Wiegand terminologicznie oddziela komponent praktyczny od teoretycznego i nie podziela stanowiska, że leksykografia, a dokładniej: naukowa leksykografia językowa, dzieli się na praktyczną i teoretyczną. Uważa, że wszelka aktywność, która nie jest częścią procesu leksykograficznego, zatem nie jest bezpośrednio nakierowana na powstanie publikacji leksykograficznej (słownika językowego), nie powinna być nazywana leksykografią ${ }^{3}$. Teoretyczne rozważania $w$ ramach procesu leksykograficznego, niezbędne przy rozwiązywaniu problemów pojawiających się w trakcie pracy nad słownikiem, także w fazie opracowywania koncepcji, które, jak wynika z wcześniejszego przeglądu, inni badacze zaliczają do teorii leksykograficznej, nie tworzą zdaniem Wieganda teorii leksykograficznej, lecz są refleksją leksykograficzną, nieodłącznym składnikiem leksykografii (językowej), czyli praktyki. Natomiast obszar naukowy dla leksykografii stanowi metaleksykografia, a w odniesieniu do słowników językowych jej część zwa-

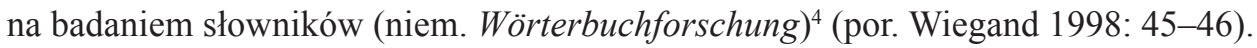

3 T. Piotrowski (2001: 27), cytując Wieganda (1983) [właśc. 1984 - M.B.] pisze: „Leksykografia nigdy nie była nauką, nie jest nauką i prawdopodobnie nie będzie nauką”, co bez dodatkowych wyjaśnień wypacza stanowisko Wieganda. Czytelnik może wysnuć fałszywy wniosek, że leksykografia jest tu rozumiana jako teoria i praktyka - zwłaszcza że wcześniej przytaczana jest taka właśnie definicja W. Miodunki (1989: 55) - i że obu komponentom Wiegand odmawia (uzyskania kiedykolwiek) statusu nauki. U Wieganda nie ma jednego terminu nadrzędnego wobec leksykografii i metaleksykografii. Autor wskazuje na podobieństwo tej sytuacji do innych, np. języka i językoznawstwa, literatury i literaturoznawstwa czy przekładu i przekładoznawstwa (por. Wiegand 1998: 75).

4 'Metalexikographie' jest według Wieganda hiperonimem 'Wörterbuchforschung', ale wielu badaczy niemieckich traktuje te określenia synonimicznie. 
Podział stanowisk prezentowanych w słownikach ogólnych, leksykonach i literaturze naukowej na trzy grupy:

- leksykografia to tylko praktyka,

- leksykografia to praktyka i teoria,

- leksykografia to tylko teoria, jest, jak widać, podziałem uproszczonym, a grupy są wewnętrznie heterogeniczne. Z braku definicji wyjściowych (por. Adamska-Sałaciak 2019; Bielińska (w druku), Piotrowski 2013) podział opiera się w dużej mierze na samych etykietkach nadanych przez autorów pewnym obszarom działalności leksykograficznej. Bez sprecyzowania, czym jest praktyka, stanowisko, że leksykografia to tylko praktyka, wcale nie wyklucza włączenia do niej rozważań teoretycznych. Praca nad słownikiem nie sprowadza się do samego tworzenia opisu leksykograficznego, tj. pisania. Ten etap poprzedzony jest opracowaniem koncepcji i wypracowaniem metod, a procesowi pisania ciągle towarzyszy refleksja nad tym, co i jak powstaje. Pogląd, że leksykografia to praktyka polegająca na zestawianiu słownika, ale i teoria, rozumiana jako nauka o metodach opracowywania słowników, nie różni się więc w istotny sposób od poprzedniego - że leksykografia to tylko praktyka. Różnica tkwi głównie w sformułowaniu i nie dotyczy sedna. Można więc, nieco upraszczając, stwierdzić, że ujmowanie leksykografii jako praktyki i teorii przy jednoczesnym redukowaniu tej ostatniej w sposób przedstawiony powyżej, czyli według Wieganda do refleksji teoretycznej, która jest nieodłącznym składnikiem większości ludzkich działań praktycznych, jest tożsame z pojmowaniem leksykografii wyłącznie jako (szerzej ujętej) praktyki.

Najwłaściwszy z dzisiejszego punktu widzenia podejściem do problemu praktyki i teorii leksykografii wydaje się pogląd, że leksykografia składa się z komponentu praktycznego i teoretycznego, przy czym tego ostatniego nie redukuje się do pomocniczej nauki o metodach zestawiania słowników, lecz uwzględnia się cały dorobek współczesnej metaleksykografii.

\section{Leksykografia a językoznawstwo}

3.1. Na wstępie należy zaznaczyć, że rozważania na temat stosunku leksykografii do językoznawstwa dotyczą jedynie leksykografii językowej. Autorzy prac naukowych zajmujący się tą kwestią z reguły wyjaśniają, że pisząc „leksykografia”, mają na myśli wyłącznie tę jej część.

EJP jako publikacja z zakresu językoznawstwa niejako w domyśle obszar leksykografii zawęża: „Leksykografia jest działem językoznawstwa stosowanego [...]” (Laskowski 1999: 209), choć zalecane byłoby tu wyraźne wskazanie na leksykografię językową. Natomiast w EJO uwzględniono także leksykografię encyklopedyczną, ale dość niefortunnie sformułowano definicję, łącząc z językoznawstwem nawet encyklopedie, niemające z tą dyscypliną nic wspólnego: „2. Nauka, której przedmiotem są słowniki różnych rodzajów (w tym językowe i encyklopedyczne, encyklopedie), uważana za dział językoznawstwa" (Lewicki 1999: 331). 
Niektóre słowniki języka polskiego zaliczają leksykografię do językoznawstwa poprzez użycie kwalifikatora jęz. (np. SJPDor; USJP) i/lub w definicji: ,dział językoznawstwa stosowanego [...]” (WSJP), „dział językoznawstwa [...]” (USJP) - nie informując użytkownika, że zredukowano tu leksykografię do leksykografii językowej. Bez eksplicytnego zawężenia wynika z tych haseł, że cała leksykografia, czyli także leksykografia encyklopedyczna, należy do językoznawstwa, z czym nie zgodziliby się nawet badacze twierdzący, że leksykografia językowa jest dyscypliną lingwistyczną. Między publikacjami encyklopedycznymi, np. słownikami biograficznymi, encyklopediami ogólnymi, leksykonami muzyki, techniki itd. a językoznawstwem nie ma żadnych związków (wyłączając jedynie leksykony z zakresu językoznawstwa). Perspektywa autorów słowników językowych oraz specjalne znaczenie leksykografii językowej w wymiarze historycznym i współczesnym spowodowały w powyższych przypadkach całkowite pominięcie drugiego obszaru leksykografii i tym samym doprowadziły do sporządzenia nieprawidłowych opisów słownikowych.

Pogląd, że leksykografia językowa jest gałęzią językoznawstwa bądź językoznawstwa stosowanego i/lub że teoria leksykograficzna bazuje na językoznawstwie bądź je st teorią lingwistyczną (p. pkt 2), jest dość rozpowszechniony w literaturze naukowej. Za dziedzinę badań lingwistycznych uważa leksykografię m.in. W. Miodunka (1989: 52), podobnie P. Żmigrodzki (2008: 21), określający leksykografię jako integralną część językoznawstwa. Maciej Grochowski (1982: 34) i Ireneusz Bobrowski (1998: 119) zaliczają leksykografię do językoznawstwa stosowanego, choć Grochowski (2004: 8) zaznacza, iż „,(n)ie są wykluczone również inne lapidarne charakterystyki relacyjne tej sfery ludzkiej działalności poznawczej [...]". Stanowiska jak powyższe nie są specyficzne jedynie dla badaczy z kręgu językoznawstwa polonistycznego. Hans Meier (2003: 307) stwierdza: ,dictionary making, though often regarded as 'a special technique rather than a branch of linguistics', may be considered an instance of applied linguistics", przy czym trzeba zauważyć, że odnosi się on wyłącznie do praktyki leksykograficznej. Podobnego zdania jest Laurence Urdang (1963: 594), a Pius ten Hacken (2009: 399) uważa, że podstawa językoznawcza jest warunkiem koniecznym do uznania leksykografii za aktywność naukową. Także John M. Sinclair (1984: 7) twierdzi, że nie ma teorii leksykograficznej i że teoretyczną podstawę leksykografii należy znaleźć ,in or via the areas of linguistics and information technology". Według Dirka Geeraertsa (1987: 1) leksykografia jest częścią lingwistyki. Trudno, jak pisze, uzasadnić rozpowszechniony pogląd, że jest dziedziną lingwistyki stosowanej, gdyż właściwie niemożliwe jest znalezienie odpowiedzi na pytanie ,what linguistic theory lexicography might be an application of" (por. Tarp 2010: 452-453; Bergenholtz, Gouws 2012: 36).

Przypisanie leksykografii językowej do językoznawstwa jest uważane często za stanowisko „naturalne”, zgodne z tradycją, a więc niewymagające obszerniejszego uzasadnienia, choć i takie się zdarzają. Autorzy wyrażający odmienne poglądy, czyli niemieszczący się w głównym nurcie, zwykle staranniej je wyjaśniają.

O tym, jak zakorzenione jest przekonanie o przynależności leksykografii językowej do językoznawstwa i jak silna jest świadomość tego zakorzenienia, świadczą 
np. następujące słowa: „Pogląd, iż leksykografia jest działem językoznawstwa [...] wydaje się oczywisty i niepodważalny. W ostatnich jednak latach niektórzy autorzy, zwłaszcza wywodzący się z grona słownikarzy praktyków, p o d w a żają status leksykografii lingwistycznej jako działu lingwistyki” (Żmigrodzki 2008: 20; wyróżnienie M.B.). Należy dodać, że poza kręgami polonistycznymi nie tylko słownikarze praktycy są odmiennego zdania. W podobnym duchu pisze M. Bańko (2001: 10): „Wśród językoznawców rozpowszechnione jest przekonanie, że leksykografia jest działem językoznawstwa (czasem dodaje się dla ścisłości - stosowanego)”, kontynuując: „Leksykografowie natomiast skłonni są postrzegać swoją pracę raczej jako rodzaj sztuki niż nauki”. M. Bańko, co potwierdza dalszy tok jego wywodu, ma na myśli wyłącznie leksykografów praktyków, niezajmujących się leksykografią jako nauką, a nie badaczy, czyli metaleksykografów. T. Piotrowski (1994: 10-11), reprezentujący stanowisko, że ,[...] słownikarstwo jest dziedziną autonomiczną, która w dużej mierze korzysta z metod analizy językoznawczej, choć często także stosuje własne zasady opisu takiego materiału, który nie wchodzi w zakres zainteresowań językoznawstwa. [...]”, uzupełnia, że ,[...] tradycyjnie leksykografię włącza się w zakres językoznawstwa [...]" (s. 10). Odwołuje się tym samym do bardzo krótkiej i nowej „tradycji” w porównaniu z kilkoma tysiącami lat słownikarstwa (por. Bielińska 2014: 214). Na fakt, że leksykografia „znajdowała się przez wiele stuleci poza językoznawstwem [...]”, zwraca uwagę W. Miodunka (1989: 53), podkreślając (,trzeba to powiedzieć”), iż okoliczności te mogą nie być powszechnie znane. Opinia Piotrowskiego na temat statusu leksykografii została ostro skrytykowana:

T. Piotrowski odrywa leksykografię od językoznawstwa, zapominając, że bez językoznawczego punktu odniesienia opisywane słowniki stają się zbiorem propozycji wydawców, zbiorem konwencji, które trudno oceniać. Pozbawiona związków z językoznawstwem leksykografia traci swe podstawy teoretyczne i staje się tylko ,praktyką układania słowników” [...].Gdyby autor przyjął, że leksykografia należy do językoznawstwa stosowanego, można by powiedzieć, że - zapominając o podstawach językoznawczych - zwraca on należytą uwagę na aspekt stosowany tego językoznawstwa (Miodunka 1995: 74).

Z perspektywy badacza leksykografii nieuznającego jej za część językoznawstwa ta krytyka jest nie do końca zrozumiała. Samo przypisanie leksykografii statusu dziedziny autonomicznej nie powoduje oderwania jej od językoznawstwa. Związki te nadal są silne, a to ze względu na przedmiot opisu w słownikach językowych, czyli język. Wiedza lingwistyczna czy też, językoznawczy punkt odniesienia” odgrywa niezależnie od statusu przypisywanego leksykografii wielką rolę przy opracowywaniu słowników językowych licznych, choć nie wszystkich typów. Nie ma to wpływu na status leksykografii jako takiej. Od czasu ukazania się recenzji monografii Piotrowskiego minęło już prawie 25 lat, w czasie których nastąpił wielki rozwój metaleksykografii. Teraz taka opinia może nie zostałaby sformułowana. Kontrowersje w środowisku polonistycznym wywołał także tytuł późniejszej pracy Bańki (2001): Z pogranicza leksykografii i językoznawstwa. Zdaniem Żmigrodzkiego (2008: 21) jest tu ,sugestia jeszcze bardziej śmiała niż w książce Piotrowskiego: leksykografia i językoznawstwo to całkowicie odrębne dyscypliny, mające tylko określoną wspólną część pola badawczego". 
3.2. Przy próbach dyscyplinarnego zakotwiczenia leksykografii wiele uwagi poświęca się leksykologii jako działowi językoznawstwa szczególnie ważnemu w tym kontekście. Sama leksykologia jest tworem równie problematycznym jak leksykografia. W zależności od tradycji badawczej traktowana jest jako odrębna dyscyplina, jako pole badawcze lub konglomerat kilku dyscyplin, np. semantyki, stylistyki czy onomastyki (por. Grochowski 1982: 15-22; Schippan 1984: 26-27; Wolski 2005: 1816-1819). Należy zwrócić uwagę także na zróżnicowanie rozpowszechnienia określenia „leksykologia”, a tym samym znaczenia tak wyodrębnionego nurtu badań w lingwistyce światowej w lingwistyce amerykańskiej czy brytyjskiej jest ono o wiele mniejsze niż w niemieckiej, francuskiej czy rosyjskiej.

Pewien zamęt wywołuje również wcześniejsze utożsamianie leksykologii z leksykografią, por.: „For more than a century lexicology was confused with lexicography [...]” (Quemada 1972: 397, za Wolskim 2005: 1817). Takie rozumienie leksykologii znajduje odbicie m.in. w starszych słownikach języka polskiego. Słownik wileński definiuje leksykologię jako naukę „o słownikach i ich układaniu”, słownik Arcta jako naukę „o pochodzeniu, znaczeniu i używaniu wyrazów, słownikarstwo”, natomiast słownik warszawski podaje dwa znaczenia: 1. „nauka o układaniu słowników, o słownikach" oraz 2. „nauka o znaczeniu i używaniu wyrazów, słownikarstwo, słownikoznawstwo”. Definicje znaczenia pojawiającego się tu słowa "słownikarstwo" potwierdzają tezę o zamiennym używaniu terminów 'leksykografia' i 'leksykologia'. Słownikarstwo to według słownika wileńskiego „Słownictwo, leksykografja, leksykologja, układanie słowników, nauka, sztuka, praca układania słowników [...]”, według słownika Arcta „umiejętność układania słowników, leksykologia" (pod słownictwo, słownikarstwo jako pierwsze znaczenie), a według słownika warszawskiego - „sztuka pisania słowników, pisanie słownika, leksykografja, leksykologja" (w haśle słownictwo jako pierwsze znaczenie).

Traktowanie leksykologii jako nauki o słownikach/leksykonach - w znaczeniu produktów leksykograficznych - ustąpiło z czasem miejsca pojmowaniu leksykologii wyłącznie jako nauki o słownictwie, ale związek tych dwóch dyscyplin ${ }^{5}$ pozostał bardzo ścisły, o czym świadczą m.in. tytuły licznych prac naukowych, np. Zarys leksykologii i leksykografii polskiej (Kania, Tokarski 1984), Podstawy leksykologii i leksykografi (Miodunka 1989), Lexikologie, lexikographische Theorie und lexikographische Praxis (Kempcke 1982), Gegenseitige Bedingungen von Lexikologie und Lexikographie (Bakos 1983), Zum Verhältnis von germanistischer Lexikologie und Lexikographie (Wiegand 1985), Lexikologie und Lexikographie. Eine Einführung am Beispiel deutscher Wörterbücher (Schlaefer 2002), Lexikologie und Lexikographie (Wolski 2005), Lexicology and Lexicography (Quemada 1972), Lexicology and Lexicography: Development and State of the Research (Filipec 1994), The Power of Words: Essays in Lexicography, Lexicology and Semantics (Caie i in. 2006), New Approaches to Specialized English

${ }^{5}$ Por. rozważania na temat dyscypliny w punkcie 4. 
Lexicology and Lexicography (2011). Takie zestawienia obu dyscyplin świadczą o ich bliskości, ale i o potrzebie sprecyzowania związków między nimi.

Osobliwie często w ogólnych słownikach języka polskiego, także tych nowszych, leksykologia jest przedstawiana jako teoretyczna podstawa leksykografii. Takie sformułowanie znajduje się np. w SJPSz, SJPDor, USJP, PSWP (w ISJP nie ma hasła leksykologia) ${ }^{6}$. Słowniki języka angielskiego: Collins, Webster, Macmillan, CALDT, LDOCE i ODE nie definiują leksykologii w ten sposób. W niektórych słownikach języka niemieckiego, np. D10 czy D6, są w hasłach Lexikologie odniesienia do leksykografii, w innych, np. Wahrig, HDG, WDG, DUW2003, takich odniesień brak. Niektóre leksykony językoznawcze (por. MLS, BLS, SDJO) podają, że wyniki badań leksykologicznych wykorzystywane są m.in. w leksykografii, o leksykologii jako podstawie leksykografii pisze BSL w haśle Lexikographie.

Szczególna rola, jaką dla leksykografii odgrywa leksykologia, oraz ścisły związek tych dwóch dyscyplin nie powinny prowadzić do tak generalizującej konstatacji, że leksykologia stanowi podstawę leksykografii. Przedmiot leksykografii językowej jest o wiele szerszy, a opracowanie słowników wymaga wykorzystania wyników badań innych działów językoznawstwa i nie tylko, np. gramatyki, która jest podstawą wielu opisów leksykograficznych, m.in. w słownikach walencyjnych, etymologii, historii języka i historii literatury (słowniki historyczne poszczególnych stadiów językowych, słowniki etymologiczne), dialektologii (słowniki gwarowe) i statystyki (słowniki frekwencyjne). Do słowników, których podstawy nie tworzy leksykologia, należą liczne inne, np. słowniki wymowy, słowniki ortograficzne, słowniki rymów, słowniki cytatów oraz jedno-, dwu- i wielojęzyczne słowniki fachowe, np. medyczne, techniczne, o charakterze językowym lub językowo-encyklopedycznym. Nawet w odniesieniu do współczesnych jednojęzycznych słowników ogólnych nie można twierdzić, że leksykologia jest ich podstawą. Jest jedną z dziedzin, zajmującą się problemami, które występują także w tej gałęzi leksykografii, ale nie jedyną.

Pogląd, że leksykologia jest teoretyczną, naukową podstawą leksykografii, trzeba zatem odrzucić. Teoretyczną podstawą leksykografii praktycznej jest teoria leksykograficzna - nie leksykologiczna i nie jakakolwiek inna językoznawcza. Leksykologia jest bardzo ważna dla samego opisu leksykograficznego języka, leksykografia korzysta z wyników badań leksykologicznych (jak i wyników badań innych działów językoznawstwa), ale to nie uzasadnia przypisywania jej funkcji podstawy teoretycznej dla leksykografii (por. Schippan 1984: 47; Schaeder 1987: 121; Wiegand 1998: 28)7

W niektórych pracach, głównie starszych, reprezentowane jest stanowisko jeszcze silniej łączące leksykografię z leksykologią niż przedstawione powyżej. Leksykografię

\footnotetext{
${ }^{6}$ Por. także omówienie haseł słownikowych leksykologia i leksykografia w Miodunka (1989: 9-15).

7 Por. tezy na temat stosunku leksykologii germanistycznej i leksykografii w Wiegand (1985). Pierwsza teza odzwierciedla ahistoryczny i bezpodstawny pogląd, że leksykologia, jej metody i wyniki determinują leksykografię i że teoria leksykograficzna może być jedynie teorią leksykologiczną (Wiegand 1985: 70). Kolejne dziewięć tez dostarcza argumentów za odrzuceniem pierwszej.
} 
uważa się w nich wręcz za gałąź leksykologii (np. Iskos, Lenkowa 1970: 266; Henne 1972: 35; Bondzio 1980: 182; Kempcke 1982: 44) lub za dział leksykologii stosowanej (np. SDJO) (por. zestawienia w Schaeder 1987: 120; Wiegand 1998: 26-27; Wolski 2005: 1820; DLP 226-229).

Inni badacze natomiast wyraźnie kwestionują takie umocowanie leksykografii, przy czym między jedną a drugą grupą nie da się wytyczyć granicy czasowej. O ile opinie, że leksykografia jest częścią leksykologii, typowe są dla dawniejszych publikacji, to stanowiska przeciwne nie zawsze są znakiem (chronologicznej) zmiany podejścia. Były bowiem przedstawiane w literaturze także w tym czasie, co te uznawane dziś za anachroniczne, por. np. „Die Lexikographie ist kein Zweig der Lexikologie, sondern eine selbständige, sich mit der Lexikologie aufs engste berührende Wissenschaft" (Lewkowskaja 1968: 266, za Wiegandem 1998: 27), „Dennoch kann man die Lexikographie nicht als Disziplin der Lexikologie betrachten [...]” (Schippan 1984: 47), „Das Verhältnis der Lexikographie (gleichgültig, ob als Praxis oder Theorie aufgefaßt) zur Lexikologie ist jedenfalls nicht das einer Teil-von-Relation" (Schaeder 1987: 121). Przeciwko stanowisku, że leksykografia jest leksykologią stosowaną bądź subdyscypliną leksykologii wypowiadają się także Franz Josef Hausmann (1985: 371) i H.E. Wiegand (1989: 250).

O własnej ewolucji w postrzeganiu związków między leksykografią i leksykologią pisze natomiast Miodunka (1989) w przedmowie do monografii, której pierwotna koncepcja „(s)prowadzała się [...] do przedstawienia leksykologii jako nauki o znaczeniu i funkcjonowaniu wyrazów, leksykografii zaś - wyłącznie jako leksykologii stosowanej" (Miodunka 1989: 5). Podczas badania związków między leksykologią a leksykografią autor „doszedł [...] do przekonania, że leksykologia i leksykografia to dwa działy językoznawstwa (czystego i stosowanego), które - jakkolwiek od dawna ze sobą powiązane - są autonomiczne i dlatego jeden z nich nie może być uznawany wyłącznie za stosowaną odmianę drugiego".

Podobnie jak w rozważaniach, czy leksykologia jest teoretyczną podstawą leksykografii (por. Wiegand 1985, p. przypis 7), przy ustalaniu, czy leksykografia jest subdyscypliną leksykologii, niezbędne jest według Wieganda (1998: 29) uwzględnienie perspektywy historycznej, umożliwiającej bardziej zróżnicowany i pełniejszy ogląd. Na przykładzie języka niemieckiego - ten mechanizm dotyczy także innych języków - widać, że słowniki są starsze niż jakiekolwiek działania, które mogą być nazwane leksykologią (germanistyczną). Dawne badanie słownictwa było właściwie pisaniem słowników, teoria i praktyka stanowiły w tym wypadku jedność, przenikały się wzajemnie. Dobrze funkcjonującej praktyki nie obudowywano osobną teorią, nie problematyzowano jej. Dopiero w XVII-XIX w. miały miejsce wielkie dyskusje programowe towarzyszące ważnym przedsięwzięciom leksykograficznym. W dyskusjach tych zastanawiano się, jakie powinny być słowniki języka niemieckiego, aby służyły określonym celom politycznym, kulturalnym, pedagogicznym i in. Kwestie leksykologiczne poruszane były jedynie na marginesie lub całkowicie pomijane. Nurt badań, który można określić leksykologią, wyodrębnił się nie wcześniej niż w XIX w. Leksykografia językowa nie jest więc gałęzią leksykologii. Leksykologia, pod niewielkim wpływem językoznawstwa, 
narodziła się z leksykografii językowej, przynajmniej w niemieckim obszarze językowym. Wiegand nazywa leksykologię późnym dzieckiem leksykografii językowej i językoznawstwa (por. Wiegand 1998: 29-32, por. także przegląd u Wolskiego 2005: 1822-1826).

Stosunek między leksykologią a leksykografią językową określany jest czasem mianem wzajemnego czerpania i dawania (np. Bakos 1983; Hausmann 1985; Schippan 1984; Kühn 1994; por. Wolski 2005: 1816). Z jednej strony leksykografia wykorzystuje wyniki leksykologii, zwłaszcza w zakresie opisu znaczenia jednostek leksykalnych, a z drugiej leksykologia otrzymuje od leksykografii impulsy naukowe. Słowniki stanowią ważną pomoc w badaniach leksykologicznych, a w przypadku badań historycznych są wykorzystywane jako źródła.

3.3. Reprezentowane w niniejszej pracy stanowisko na temat statusu leksykografii zostało zasygnalizowane w poprzednich jego częściach - leksykografia (językowa) nie jest częścią językoznawstwa bądź językoznawstwa stosowanego czy leksykologii, a teoria leksykograficzna nie jest tożsama z teorią językoznawczą ani węziej: leksykologiczną. Kwestia stosunku leksykografii i leksykologii wydaje się omówiona wystarczająco dokładnie, natomiast opinia ogólniejsza, że leksykografia (językowa) nie jest częścią językoznawstwa, wymaga jeszcze wyjaśnienia. Argument historyczny, genetyczny, czyli fakt, że leksykologia pojmowana w sposób współczesny oraz językoznawstwo jako dyscyplina badań akademickich (sama refleksja nad językiem jest o wiele starsza) narodziły się później niż leksykografia, nie jest tu przesądzający. Istotniejsze są inne argumenty przemawiające przeciwko włączaniu leksykografii językowej do językoznawstwa.

Leksykografia praktyczna rozwijała się przez kilka tysięcy lat, bazując na własnych doświadczeniach. Kształtował ją przede wszystkim zmieniający się duch czasu - kultura, ideologia, sytuacja polityczno-społeczna i gospodarcza, potrzeby komunikacyjne użytkowników oraz cele stawiane sobie przez samych leksykografów, np. patriotyczne czy pedagogiczne. Prądy i szkoły językoznawcze miały i mają na leksykografię o wiele mniejszy wpływ, nawet jeśli weźmie się pod uwagę jedynie ten stosunkowo krótki okres, w którym można już mówić o językoznawstwie w dzisiejszym znaczeniu. Dystans między leksykografią a teoriami lingwistycznymi jest często znaczny. Wyniki badań lingwistycznych zwykle nie przenikają szybko do leksykografii, do czego przyczynia się zarówno zachowawczy charakter opisów leksykograficznych języka (przyczyn tego tradycjonalizmu jest wiele, wśród nich są także przyczyny ekonomiczne), jak i charakter samych badań lingwistycznych i ich wyników. Nie wszystko, co jest wartościowe poznawczo dla językoznawstwa, niesie wartość dla leksykografii praktycznej.

Nie znaczy to jednak, że językoznawstwo nie odgrywa żadnej roli w leksykografii. Językoznawstwo, jak to zostało podkreślone uprzednio, jest dyscypliną dostarczającą leksykografii językowej wielu ważnych danych, a leksykografowie praktycy stosują w swej pracy wybrane metody lingwistyczne. Wyniki badań lingwistycznych są wykorzystywane w opisach leksykograficznych, które w zależności od typu i funkcji słownika mogą zawierać informacje o wymowie danej jednostki leksykalnej, o jej wariantach 
ortograficznych, właściwościach fleksyjnych i składniowych, znaczeniu, potencjale kombinatorycznym, pochodzeniu itd. Leksykografia dwujęzyczna korzysta z wyników badań kontrastywnych. Wielki wpływ na współczesną leksykografię wywiera lingwistyka korpusowa (por. Bielińska 2014: 222).

Jednakże fakt, że w leksykografii wykorzystywane są wyniki i metody językoznawstwa, a w przypadku wielu rodzajów słowników językowych potrzebna jest wiedza językoznawcza (z zakresu gramatyki, semantyki, etymologii itd.), nie czyni z leksykografii (działu) językoznawstwa. Leksykografia korzysta także z metod innych dyscyplin - również nie będąc ich częścią - oraz z własnych, specyficznych dla leksykografii. Argumentem za włączeniem leksykografii do językoznawstwa nie jest także fakt, że wśród leksykografów opracowujących słowniki językowe jest wielu językoznawców. Tak jak argumentem za włączeniem leksykografii do biologii czy energetyki nie jest fakt, że przy sporządzaniu słowników specjalistycznych z tych dziedzin (słowników językowych, językowo-encyklopedycznych lub encyklopedycznych) leksykograf musi być wyposażony w odpowiednią wiedzę, czyli jest zazwyczaj biologiem lub inżynierem energetykiem. To tylko świadczy o tym, że w zależności od przedmiotu opisu leksykograficznego poza umiejętnościami leksykograficznymi potrzebna jest wiedza z tego czy innego zakresu. Wykształcenie i profesja autora słownika - czy jest to językoznawca, czy biolog - nie mają wpływu na status samej leksykografii.

Za stanowiskiem, że leksykografia nie jest działem językoznawstwa, przemawiają kolejne argumenty, gdy w odniesieniu do praktyki leksykograficznej wyraźnie rozdzieli się aspekty leksykograficzne i językoznawcze. Opisu leksykograficznego nie można utożsamiać z opisem lingwistycznym, a decyzji leksykograficznych podejmowanych $\mathrm{w}$ trakcie opracowywania słownika $\mathrm{z}$ decyzjami lingwistycznymi. Przy konstrukcji opisu leksykograficznego brane są pod uwagę czynniki, które w opisie lingwistycznym nie są istotne (i odwrotnie), a na wielu etapach procesu leksykograficznego dominują decyzje o charakterze leksykograficznym, niemające żadnego związku z językoznawstwem.

Opracowując koncepcję słownika, należy przede wszystkim zaplanować, co będzie opisane dla kogo i po co, tj. określić przedmiot opisu leksykograficznego, adresata słownika oraz sytuacje, w których słownik będzie używany, i jego funkcje. Istotne jest także ustalenie wielkości publikacji, gdyż ma to wpływ na kolejne decyzje leksykograficzne i na stronę organizacyjną oraz finansową przedsięwzięcia, które w dalszych rozważaniach zostaną pominięte. W przypadku słowników językowych przedmiotem opisu leksykograficznego może być współczesny język etniczny, dwa języki lub więcej, język w stadium historycznym, język wybranego pisarza, odmiana terytorialna, język pewnej grupy społecznej, słownictwo specjalistyczne z danej dziedziny i in. Opisywane mogą być też jednostki leksykalne wyłącznie o określonych cechach, np. frazeologizmy, kolokacje, archaizmy bądź też określone właściwości jednostek leksykalnych, np. ich wymowa (w przypadku słownika wymowy), pisownia (w słowniku ortograficznym) czy relacje paradygmatyczne $\mathrm{z}$ innymi jednostkami (np. w słowniku synonimów i słowniku antonimów). Wybór przedmiotu opisu to decyzja o charakterze leksykograficznym, nie językoznawczym. Ustalenie objętości słownika jest także sprawą leksykograficzną. 
Na przykład koncepcja słownika pedagogicznego dla początkujących może zakładać, że słownik obejmie ok. 5 tysięcy jednostek leksykalnych, które są przydatne na pierwszym etapie nauki danego języka jako obcego. I dopiero po tej decyzji leksykograficznej następuje na bazie językoznawczej, tj. na podstawie wyników badań lingwistycznych, wybór jednostek leksykalnych, które są najczęstsze, najprzydatniejsze w komunikacji itd.

Kluczową kwestią jest wybór adresata. Profil potencjalnego odbiorcy, czyli wiek, kwalifikacje, znajomość opisywanego w słowniku języka i sytuacje, w których użyje słownika, powinien być określony na samym początku pracy leksykograficznej, gdyż ma wpływ na zawartość i formę słownika. Jako użytkownicy słownika dorośli różnią się od dzieci, rodzimi użytkownicy języka od uczących się danego języka jako obcego (tych ostatnich powinno się ponadto zróżnicować według stopnia opanowania języka), a specjaliści od laików. Dlatego też np. słownik języka angielskiego dla początkujących cudzoziemców, którzy mają używać go przy produkcji tekstu, będzie zawierał znacznie mniej haseł niż słownik dla rodzimych użytkowników języka angielskiego, a opis ujętych jednostek leksykalnych powinien umożliwić odbiorcy poznanie znaczenia oraz poprawne użycie danego leksemu w tekście. Potrzebna jest więc m.in. prosta leksykalnie i składniowo definicja leksykograficzna i szczegółowe informacje gramatyczne zaprezentowane w nieskomprymowanej formie, podczas gdy np. informacje etymologiczne czy informacje o znaczeniach i/lub formach przestarzałych bądź rzadkich są zbyteczne. Podobnie jak wybór przedmiotu opisu wybór adresata oraz koncepcyjne dopasowanie formy i zawartości słownika językowego do potrzeb i możliwości zakładanego użytkownika nie jest zadaniem językoznawczym, lecz leksykograficznym.

Przytoczone uprzednio (por. pkt 3.1) zdanie Miodunki, że w przeszłości leksykografia nie była częścią językoznawstwa, rozwinięte jest przez autora w sposób następujący: „Owszem, układający słownik znał i brał pod uwagę ówczesny stan wiedzy o języku, jednakże wybierał zeń to, co jego zdaniem było niezbędne, by zaspokoić oczekiwania odbiorców" (Miodunka 1989: 53). Paradoksalnie, chcąc podkreślić odmienny charakter dawnej leksykografii, Miodunka trafnie oddał (pożądaną) sytuację aktualną. Postulat dostosowania słowników do potrzeb użytkowników - czy to w przypadku słowników popularnych dla szerokich kręgów adresatów, czy też słowników przeznaczonych dla wąskiej grupy specjalistów, np. badaczy języka - należy obecnie do najważniejszych wytycznych w praktyce leksykograficznej. Słowniki nie mają być wyłącznie skarbnicą wszelkich informacji o języku przeznaczonych dla bliżej nieokreślonego odbiorcy, powinny przede wszystkim efektywnie służyć pomocą wybranej grupie użytkowników w określonych sytuacjach. Dlatego też przy opracowywaniu ich koncepcji musi być uwzględniony profil adresata: „Dictionaries should be designed with a special set of users in mind and for their specific needs" (Householder 1962: 279, za Bogaardsem 1994: 192).

Także zaplanowanie budowy słownika i zawartości jego poszczególnych części wymaga podjęcia szeregu decyzji o charakterze leksykograficznym, a nie językoznawczym. W zakresie megastruktury należy ustalić, jakie komponenty będzie zawierać słownik poza częścią hasłową i jaka będzie dystrybucja danych. Jeśli chodzi o część hasłową, istotne jest z jednej strony wyznaczenie typu układu haseł, z drugiej zaś wypracowanie 
zasad selekcji zewnętrznej oraz lematyzacji. Określony zostaje także, jeśli jest to konieczne w danym słowniku, sposób traktowania homonimii i polisemii, nazw własnych, skrótów, form supletywnych, leksemów wielowyrazowych, wariantów wyrazu hasłowego i in. Do każdego typu lematyzowanej jednostki musi być dokładnie wyznaczony sposób jej opisania w haśle, zatem należy opracować mikrostrukturę i wskazać elementy opisu leksykograficznego, które powinny się znaleźć w haśle danego typu. Ze względu na specyfikę opisu słownikowego konieczne jest opracowanie spójnego systemu odsyłaczy - wewnątrzhasłowych, $\mathrm{z}$ hasła do hasła, z hasła do tekstu w części ramowej $\mathrm{i}$ in. (por. Bielińska [w przygotowaniu]).

Z powyższego wynika, że $\mathrm{w}$ trakcie procesu leksykograficznego podejmowanych jest wiele decyzji, które mają charakter jednoznacznie leksykograficzny i nie mogą być utożsamiane $\mathrm{z}$ językoznawczymi.

Decyzje, jaki wycinek słownictwa będzie rejestrował słownik, jakie informacje będą zawierały hasła, dla kogo będzie przeznaczony słownik itd., nie mają podłoża lingwistycznego, mimo iż dotyczą języka i związane są z opracowywaniem słowników językowych. To nie znaczy, że decyzje lingwistyczne nie odgrywają żadnej roli. Są niezbędne ze względu na przedmiot opisu, czyli język, ale w przypadku słowników - inaczej niż w opisach lingwistycznych - zawsze są podporządkowane decyzjom leksykograficznym, które są podejmowane przed nimi. Leksykograf musi się kierować przede wszystkim potrzebami potencjalnego użytkownika słownika, a dopiero w następnej kolejności podejmuje odpowiednie decyzje lingwistyczne dotyczące opisywanego języka.

Przykładowo, planując jednojęzyczny słownik pedagogiczny, który ma służyć jako pomoc w produkcji tekstów, leksykograf może podjąć decyzje leksykograficzne, że artykuły hasłowe będą zawierać synonimy do każdego znaczenia jednostki leksykalnej funkcjonującej jako wyraz hasłowy, że synonimy mają być zamieszczone bezpośrednio po definicji znaczenia oraz że przeznaczona na nie pozycja w mikrostrukturze może być wypełniona najwyżej trzema synonimami. Opracowując hasła tak zaplanowanego słownika, leksykograf musi dokonywać wyboru synonimów, czyli podejmować decyzje - tym razem już decyzje lingwistyczne - które z np. pięciu czy siedmiu synonimów wybrać, co jednocześnie oznacza wybór określonej koncepcji synonimii.

Podobny mechanizm działa w przypadku pozostałych aspektów opisu słownikowego - decyzje leksykograficzne są nadrzędne wobec lingwistycznych i poprzedzają te ostatnie. Prymat aspektu leksykograficznego przejawia się też w możliwości pomijania w słowniku pewnych ważnych rozróżnień lingwistycznych lub innego podejścia do nich niż stosowane w językoznawstwie. Przykładem może być traktowanie homonimii i polisemii w słownikach (maksymalizacja homonimii lub maksymalizacja polisemii) czy też nieuwzględnianie w opisie leksykograficznym różnorodności typologicznej frazeologizmów, jeśli jest to nieistotne z punktu widzenia użytkowników danego słownika (por. Wiegand 2013: 21-22).

Mimo iż opis leksykograficzny w słownikach językowych zawiera informacje lingwistyczne, nie jest opisem lingwistycznym i nie musi odzwierciedlać określonych teorii językoznawczych. Wyjątek stanowią słowniki specjalistyczne przeznaczone dla badaczy 
języka, będące zapisem badań lingwistycznych w formie słownikowej. Tutaj rola teorii lingwistycznych, a także decyzji lingwistycznych, jest nieporównywalnie większa, a zadaniem słownika jest przedstawienie opisu całkowicie zgodnego z wybraną teorią. Należy jednak podkreślić, że teoria lingwistyczna ma zastosowanie jedynie w odniesieniu do samego przedmiotu opisu leksykograficznego, a nie do słownika jako całości, jako formy przedstawienia materiału, oraz że decyzje bazujące na wiedzy językoznawczej - kluczowe dla prawidłowości opisu - nadal są podporządkowane decyzjom leksykograficznym podjętym w czasie opracowywania koncepcji słownika (por. Wiegand 2013: 28-29).

Powyższe rozważania można zamknąć konkluzją, że wiedza lingwistyczna jest w przypadku słowników językowych niezbędna przy sporządzaniu opisu języka, decyzje na niej bazujące warunkują jakość tego opisu, ale językoznawstwo nie jest podstawą praktyki leksykograficznej.

Pod kątem związków z językoznawstwem należy zbadać również leksykografię teoretyczną. Za punkt wyjścia niech posłuży wypowiedź Piotrowskiego (2001: 31):

\footnotetext{
Zdroworozsądkowo leksykografia teoretyczna powinna zajmować się teoretycznymi podstawami układania słowników. Jednak, jeżeli słownik ma traktować o języku, to co nowego leksykografia teoretyczna może dać leksykografowi, co nie jest tożsame z ustaleniami językoznawstwa? Czy istnieją jakieś teoretyczne zagadnienia, które nie są językoznawcze?
}

Te pytania, mimo iż w zamierzeniu autora raczej prowokacyjne, dobrze odzwierciedlają przedstawione wyżej stanowisko reprezentowane przez część językoznawców, że teoretyczną podstawę leksykografii stanowi językoznawstwo, a w konsekwencji, że leksykografia należy do językoznawstwa. Koncentracja na aspektach teoretycznych pozwala dostrzec podstawową różnicę między tymi dwiema dyscyplinami, która wyklucza uznanie jednej za część drugiej:

Obiekty badań językoznawstwa i leksykografi sa różne. Obiektem badań językoznawczych jest język, natomiast obiektem badań leksykografii, także językowej, jest stownik.

Wyraźnie rozróżnienie obiektów badawczych jest konieczne, zwłaszcza że z jednej strony badania lingwistyczne mogą bazować na słownikach, $\mathrm{z}$ drugiej zaś badania leksykograficzne mogą dotyczyć jednostek języka.

Przykładem badań pierwszego typu, czyli językoznawczych, jest badanie pod wybranym aspektem lub wieloma aspektami pewnego zbioru jednostek leksykalnych, np. archaizmów, frazeologizmów, złożeń, czasowników przechodnich etc., pozyskanych według rozmaitych kryteriów ze słownika lub słowników. Takie badanie, mimo iż oparte na materiale słownikowym, nie ma charakteru leksykograficznego. To właśnie badanie lingwistyczne, które dostarcza informacji o języku. Jego obiektem są jednostki języka, a wnioski dotyczą języka, a nie słownika, który był tylko źródłem materiału leksykalnego.

Natomiast badanie opisów leksykograficznych archaizmów, frazeologizmów etc. przykładowo badanie selekcji, lematyzacji, definicji i innych elementów artykułów hasłowych, systemu odsyłaczy, porównywanie opisów tych jednostek w słownikach dawnych i współczesnych, różnych typów i tego samego typu itd. - jest badaniem leksykograficznym. Obiektem badania leksykograficznego są słowniki i słowników 
dotyczą wnioski z takiego badania. Badanie dostarcza informacji nie o samym języku, lecz o jego opisie słownikowym.

Leksykografia teoretyczna ma więc, podobnie jak leksykografia praktyczna, punkty styczne z językoznawstwem, ale nie jest jego częścią.

Odpowiedź na pytanie „Czy istnieją jakieś teoretyczne zagadnienia, które nie są językoznawcze?" nie może być inna niż twierdząca. Jej uzasadnienie wymagałoby przedstawienia problemów badawczych metaleksykografii, a dokładniej: jej poszczególnych działów - systematycznego, historycznego i krytycznego badania słowników oraz badania użycia słownika (te zagadnienia zostaną omówione dokładniej w punkcie 4).

Podsumowując - w przypadku leksykografii językowej, tak ściśle związanej z językiem i językoznawstwem, nie należy ani jej komponentu praktycznego postrzegać jako części językoznawstwa (stosowanego), ani leksykografii teoretycznej włączać do językoznawstwa. Za oddzieleniem obu dyscyplin przemawiają argumenty historyczne, leksykograficzny, czyli niezwiązany z lingwistyką, charakter nadrzędnych decyzji podejmowanych w trakcie procesu tworzenia słownika oraz odrębne obiekty badań (słownik vs język). Zastosowanie metod lingwistycznych w leksykografii językowej, wykorzystywanie wiedzy językoznawczej w opisie słownikowym oraz fakt, że przedmiotem opisu w słownikach językowych jest język, nie czynią z leksykografii lingwistyki.

\section{Leksykografia jako samodzielna dyscyplina}

4.1. W tej części zostaną omówione stanowiska uznające odrębność czy też autonomiczność leksykografii. Sam tytuł Leksykografia jako samodzielna dyscyplina niewiele mówi, a jego precyzja i jednoznaczność są tylko pozorne. Użycie takiego tytułu jest zabiegiem zamierzonym i w pewnym sensie nieuniknionym, gdyż z jednej strony niektóre z prezentowanych stanowisk tak właśnie określają leksykografię i dalekie są przy tym od precyzji i jednoznaczności, z drugiej zaś sama materia nie ułatwia zadania.

W części poświęconej leksykografii jako praktyce i teorii użyte zostało w odniesieniu do leksykografii teoretycznej określenie „nauka”. Sformułowanie, że leksykografia teoretyczna jest nauką, jedynie przypisuje temu obszarowi działalności charakter naukowy, ale nie rozstrzyga kwestii statusu leksykografii - można ją uznawać za odrębną dyscyplinę naukową lub za dział innej dyscypliny, np. językoznawstwa. Kilkakrotnie we wcześniejszych rozważaniach pojawiało się w odniesieniu do leksykografii także określenie „odrębna dyscyplina”. Część badaczy przypisuje leksykografii taki status, część jej go odmawia, ale niezależnie od stanowiska nasuwają się pytania, jak pojmowana jest tu leksykografia, czy chodzi o jej komponent teoretyczny, czy także o praktyczny, a ponadto - czym jest dyscyplina i o jaki charakter dyscypliny chodzi. Bez wyjściowego zdefiniowania dwóch głównych członów stwierdzenie „Leksykografia jest / nie jest samodzielną dyscypliną" zostawia zbyt szerokie pole dla interpretacji i domysłów.

Analiza takich pojęć, jak nauka, dyscyplina czy pole badawcze, wykracza daleko poza zagadnienia leksykograficzne, więc na potrzeby dalszych wywodów można ograniczyć się do niezbędnych ustaleń dotyczących dyscypliny. W interesującym nas kontekście 
określenie „dyscyplina” może być używane w odniesieniu do rozwiniętej teoretycznie i metodologicznie dyscypliny naukowej lub dyscypliny akademickiej, wykazującej cechy dyscypliny naukowej i dyscypliny w sensie zawodowym, tj. wykształcenia zawodowego. Wiegand (1998: 90-97) odróżnia ponadto dyscyplinę naukową od dyscypliny (określenie to używane jest wtedy bez precyzujących atrybutów), która nie musi spełniać kryteriów przewidzianych dla tej pierwszej. W innych pracach leksykograficznych takie rozróżnienie nie jest dokonywane, co jednak nie znaczy, że ich autorzy zawsze precyzują, jak rozumieć stosowane przez nich określenie „dyscyplina”.

Definicje dyscypliny naukowej nie są jednolite, ale można przyjąć pewne kryteria, które muszą być spełnione, aby określona aktywność badawcza została uznana za dyscyplinę naukową (por. Wiegand 1998: 90). Jedno kryterium (implicytnie) podaje Bahr (1978: 98, za Schaederem 1987: 122), który uważa, że leksykografia na razie nie jest nauką. Według niego leksykografia może stać się nauką, jeśli leksykografom uda się swoją praktykę umocować teoretycznie i usystematyzować w ramach jednej lub wielu teorii. Na istnienie spójnej teorii jako na warunek konieczny dla uznania pola badawczego za dyscyplinę naukową wskazuje także Wiegand (1998), opierając się na katalogu kryteriów Posnera (1988). Poza tym warunkiem muszą być spełnione cztery inne: wyznaczony obszar badań, perspektywy badawcze (w przypadku badania słowników Wiegand podaje perspektywę historyczną, formalno-strukturalną, związaną z organizacją procesu leksykograficznego, dokumentacyjną, ewaluacyjną, tj. dotyczącą oceny słowników, i związaną z użyciem słowników; por. Wiegand 1998: 98), specyficzne metody oraz intersubiektywnie zrozumiałe środki opisu, a także wybrane warunki z dwóch dodatkowych zbiorów, którymi Wiegand uzupełnia katalog Posnera. Zbiory zawierają precyzyjniej opisane kryteria, pozwalające na bardziej zniuansowane podejście do zagadnienia i na wyodrębnienie oraz odróżnienie od siebie dyscyplin naukowych (por. Wiegand 1998: 95-97). Analizując status metaleksykografii - a dokładniej: jedynie części, którą nazywa badaniem słowników i którą wyraźnie oddziela od leksykografii językowej, pojmowanej jako działalność praktyczna - Wiegand dochodzi do wniosku, że nie jest to, biorąc pod uwagę jej stan w połowie lat 90. XX w., dyscyplina naukowa ani samodzielna nauka: „Die Wörterbuchforschung - so wie sie sich (mir) Mitte der 90er Jahre darstellt - ist keine wissenschaftliche Disziplin im wissenschaftstheoretischen Sinne und damit - anders gesagt - keine selbständige Einzelwissenschaft“ (Wiegand 1998: 102). Nie spełnia bowiem dwóch kryteriów - nie jest zgłębiany cały obszar badawczy i brakuje spójnej teorii. Jest to na razie jedynie pole badawcze, które z czasem może stać się dyscypliną naukową (por. s. 97-103). Komentując to stanowisko Wieganda, wyrażane także wcześniej (por. Wiegand 1989), Wolski (1997: 224) zauważa, że leksykografii, a ściślej: badaniu słowników, jako dyscyplinie naukowej stawia się tu wysokie wymagania, których nie spełnia wiele pól badawczych od dawna uznawanych bezdyskusyjnie za dyscypliny naukowe.

Antonin Kučera i in. (1985: IX, za Wiegandem 1998: 89) oraz Schaeder (1987: 6) odnotowują, że leksykografia - Kučera i in. piszą o „the study of dictionaries”, a Schaeder koncentruje się na ,die Gesamtheit der [...] wissenschaftlichen Beschäftigung mit 
deutschsprachigen Wörterbüchern" - rozwija się w kierunku samodzielnej dyscypliny, a mniej więcej w tym samym czasie Bernard Quemada (1987: 233) i F.J. Hausmann (1989: 102) traktują metaleksykografię jako (nową) dyscyplinę naukową (por. Wiegand 1998: 89). Andrzej Maria Lewicki (1999: 331) przedstawia metaleksykografię (nie używając tego terminu) jako naukę „uważan(ą) za dział językoznawstwa”, która „(p)rzez wiele wieków uprawiana jako zbiór umiejętności praktycznych, uogólnionych niekiedy we wstępach do słowników i encyklopedii, wyodrębniła się jako samodzielna dyscyplina badawcza i teoretyczna w poł. XX w.”. T. Piotrowski (1994: 10), jak wspomniano w punkcie 3.1, nazywa leksykografię „dziedziną autonomiczną”, o leksykografii jako samodzielnej dyscyplinie piszą Bergenholtz, Tarp (2003); Tarp (2008, 2010) i Bergenholtz, Gouws (2012).

Przytoczone prace łączy stanowisko, że leksykografia staje się bądź już jest samodzielną dyscypliną. Autorzy (np. Bergenholtz, Gouws 2012: 38, 40) nie zawsze precyzują, czy chodzi o dyscyplinę naukową, czyli spełniającą określone kryteria, czy też słowo „dyscyplina” użyte jest tu nie jako ściśle zdefiniowany termin. Równie nieostre jest określenie „dziedzina” u Piotrowskiego. Rozbieżności dotyczą też traktowania leksykografii. Część autorów zaznacza, iż za samodzielną dyscyplinę (naukową) uważa jedynie metaleksykografię (np. Schaeder 1987, Hausmann 1989), a część status dyscypliny przypisuje leksykografii obejmującej komponent praktyczny i teoretyczny, co zresztą nie zawsze jest jednoznacznie sformułowane i w interpretacji trzeba się posiłkować szerokim kontekstem. Ponadto w niektórych pracach przedmiotem dyskusji jest wyłącznie leksykografia językowa, podczas gdy w innych (np. Tarp 2010, Bergenholtz, Gouws 2012) autorzy traktują leksykografię całościowo, uwzględniając także leksykografię encyklopedyczną, mimo iż punktem ciężkości jest leksykografia językowa jako dokładniej i częściej badana gałąź leksykografii. Porównanie i analiza użycia określeń „samodzielna” czy „autonomiczna” (niem. eigenständig, ang. independent) w przytoczonych pracach zbytnio odbiega od głównego tematu, ale warto zaznaczyć, że opisywanie leksykografii jako dyscypliny samodzielnej czy niezależnej nie jest zaprzeczeniem jej wysoce interdyscyplinarnego charakteru, zarówno w przypadku metaleksykografii, jak i praktyki leksykograficznej.

Rozwiązania przyjęte w omówionych pracach mają następujące konsekwencje:

(1) Jeśli oba komponenty leksykografii, tj. leksykografia praktyczna i teoretyczna, traktowane są przy określaniu statusu łącznie, prowadzi to - jak pokazuje powyższy przegląd - do dwóch konstatacji, z których żadna nie jest zadowalająca.

(a) Zastosowanie rozmytych, niezdefiniowanych określeń „dyscyplina”, „dziedzina” itp. pozwala na przypisanie (całej) leksykografii takiego właśnie statusu i dzięki temu zachowana jest spójność leksykografii. Skutkiem użycia niejasnych określeń jest jednakże to, że dokładny status leksykografii nadal nie zostaje określony. Sformułowane przy takich warunkach wyjściowych zdanie, że leksykografia jest samodzielną dyscypliną, znaczy tyle, co stwierdzenie, że zajmowanie się słownikami - ich zestawianie jak i badanie - jest formą lub odrębnym obszarem aktywności ludzkiej, niewchodzącym w zakres innych obszarów. 
(b) Drugą z możliwości wybieranych przez część autorów jest użycie precyzyjnego określenia „dyscyplina naukowa” i przypisanie leksykografii, pojmowanej jako praktyka i teoria, statusu dyscypliny naukowej. Zdanie „Leksykografia jest samodzielną dyscypliną naukową" jest wprawdzie w porównaniu z powyższym bardziej informatywne, ale z kolei nieakceptowalne. Leksykografia praktyczna i leksykografia teoretyczna (metaleksykografia) to dwa odmienne rodzaje działalności, podobnie jak np. produkcja filmowa i filmoznawstwo, zajmujące się teorią filmu, jego historią i krytyką filmową. Z dwóch komponentów leksykografii tylko metaleksykografię można uznać za dyscyplinę naukową. Praktyka leksykograficzna nie może być traktowana jako nauka, jako aktywność badawcza. Leksykografowie praktycy, tworząc słowniki, nie pracują naukowo - nie badają obiektu, czyli słownika, nie stawiają hipotez, które następnie weryfikują, nie tworzą teorii, nie formułują wniosków.

Dotyczy to wszystkich rodzajów słowników, od słowników komercyjnych przeznaczonych dla szerokiej grupy adresatów po słowniki naukowe dla specjalistów. Zestawianie słowników naukowych będących formą przedstawienia wyników pracy naukowej, np. badań lingwistycznych w pewnym obszarze lub według danej teorii, nie jest bowiem pracą naukową. Pracą naukową jest etap wcześniejszy. Opis leksykograficzny jest wtórny wobec lingwistycznego. Przetworzenie w opis leksykograficzny przedstawienia wyników badań w formie opisu lingwistycznego, czyli dostosowanie go do koncepcji danego słownika, zastosowanie przyjętych konwencji opisu słownikowego, podjęcie szeregu decyzji o charakterze leksykograficznym, czyli przepuszczenie go przez „matrycę” leksykograficzną, nauką nie jest.

(2) Potraktowanie poszczególnych komponentów leksykografii osobno pozwala na uwzględnienie ich specyfiki i uniknięcie wad rozwiązania (1) przedstawionego powyżej.

Wiegand (1998) uważa leksykografię językową za praktykę, w ramach której opracowywane są słowniki. Jej celem nie jest tworzenie teorii bądź części teorii naukowej, lecz wytworzenie produktu użytkowego. Leksykografia językowa, rozumiana zgodnie z wzmiankowanym wyżej podziałem wyłącznie jako praktyka (por. pkt 2) nie jest nauką (por. Wiegand 1998: 21-23, 37). I do tak pojmowanej leksykografii odnosi się opinia: „Die Sprachlexikographie war nie eine Wissenschaft, ist derzeit keine Wissenschaft und wird wahrscheinlich auch nie eine Wissenschaft werden" (s. 23) (por. thumaczenie w przypisie 3). Badanie słowników, czyli dział metaleksykografii związany ze słownikami językowymi, nie było według Wieganda pod koniec XX w. jeszcze nauką. Dzisiaj może autor zmieniłby zdanie. Rozwiązanie Wieganda pozwala na adekwatne określenie specyfiki obu komponentów leksykografii, ale ma tę wadę, że terminologicznie oddziela je od siebie, co jest sprzeczne z rozpowszechnionym pojmowaniem leksykografii. Inni badacze, którzy w dyskusji na temat statusu leksykografii także odrębnie traktują jej komponenty i uznają, że status dyscypliny naukowej przysługuje tylko metaleksykografii, stosują termin 'leksykografia' jako hiperonim wobec leksykografii praktycznej i teoretycznej. 
Takie użycie terminu 'leksykografia', rozpowszechnione w literaturze przedmiotu i w słownikach, wydaje się optymalne, także jeśli chodzi o określenie statusu leksykografii, niezawężanej już do językowej, lecz obejmującej także językowo-encyklopedyczną oraz encyklopedyczną. Można za punkt wyjścia przyjąć, że oba komponenty tworzą całość, podkreślić tym samym spójność i odrębność leksykografii, aby w kolejnym kroku określić specyfikę obu części. Leksykografia obejmuje praktykę, w ramach której opracowywane są publikacje leksykograficzne, oraz naukę, czyli metaleksykografię. Leksykografia praktyczna tworzy produkty zaspokajające potrzeby społeczne i jednocześnie dostarcza leksykografii teoretycznej materiału do badań.

4.2. Głównym tematem kolejnej części wywodu jest metaleksykografia jako samodzielna dyscyplina naukowa. Mimo iż nie ograniczamy się do leksykografii językowej (odmiennie niż w punkcie 3), rozważania opierają się na badaniach przeprowadzonych w ramach leksykografii językowej. Słowniki językowe są bowiem badane i opisywane od wieków. To zawężenie nie wpływa jednak na kluczowe wnioski, gdyż głównym założeniem, o którym była już mowa, jest oddzielenie rozważań o statusie i ogólnej naturze leksykografii od przedmiotu opisu leksykograficznego. Dość trafnie oddają podstawę rozdziału sposobu leksykograficznego opisu określonego przedmiotu od samego przedmiotu tego opisu słowa Barbary Otwinowskiej: „Słownik to raczej metoda niż zawartość" (Otwinowska 1998: 881, za Piotrowskim 2001: 24). Przedmiot opisu słownikowego nie ma wpływu na status leksykografii. Nie można przypisywać odmiennego statusu poszczególnym gałęziom leksykografii na podstawie tego, co jest w danej gałęzi przedmiotem opisu słownikowego. Jeśli uznalibyśmy leksykografię językową za dział językoznawstwa, to za dział jakiej dyscypliny należałoby uznać leksykografię encyklopedyczną w całej swej różnorodności? W zależności od przedmiotu opisu leksykografia byłaby działem medycyny, techniki, historii, ekonomii etc.

Opierając się na definicji nauki ${ }^{8}$, S. Tarp (2008) twierdzi, że leksykografia spełnia wszystkie wymogi stawiane dziedzinom aktywności człowieka, które są uważane za odrębną naukę czy dyscyplinę akademicką:

- posiada własny przedmiot badań,

- jest zakorzeniona w pojęciach, kategoriach, teoriach i hipotezach,

- obejmuje historię słowników oraz własną, włączając w nią idee „przedteoretyczne”,

- rozwinęła metodologię

oraz

- formułuje wskazówki do działań praktycznych.

Jej celem jest poszerzenie wiedzy o słownikach jako produktach zaspokajających specyficzne potrzeby społeczne i przyczynienie się do powstawania lepszych słowników (por. Tarp 2008: 4, 6).

Wśród argumentów przemawiających przeciw włączaniu leksykografii językowej do językoznawstwa (p. punkt 3) przytoczony został argument o odrębnych obiektach badań (słownik językowy vs język). Istnienie odrębnego obiektu badań, specyficznego

${ }^{8}$ Definicja pochodzi z $\mathrm{PhW}(1083,1169)$. 
dla danej dyscypliny, ale nie dla innych dyscyplin, nawet z nią powiązanych, jest jednocześnie argumentem za uznaniem leksykografii za samodzielną dyscyplinę naukową (por. Tarp 2010: 455). Obiektem badań leksykografii teoretycznej, nie ograniczając jej już do językowej, są publikacje leksykograficzne. To ogólne określenie może być uznane za adekwatniejsze niż określenie „słownik”, przypisywane często tylko słownikom językowym. Przez pojęcie publikacji leksykograficznych rozumiemy wszystkie produkty leksykografii - językowe, językowo-encyklopedyczne oraz encyklopedyczne.

Specyficzny obiekt badawczy wymaga specyficznej terminologii. Do opisu, analizy i przedstawiania wyników badań publikacji leksykograficznych metaleksykografia wykształciła własny język specjalistyczny. Z powodu interdyscyplinarnego charakteru leksykografii język ten przenika do języków innych dyscyplin, a z drugiej strony przejmuje ich terminologię. Jednak trzon stanowi terminologia specyficzna jedynie dla leksykografii. Jej stopień rozbudowania jest różny w poszczególnych językach, co jest konsekwencją różnic ilościowych i jakościowych między badaniami metaleksykograficznymi prowadzonymi w poszczególnych krajach. Wydaje się, że obecnie najbogatsza jest terminologia niemiecka (więcej o języku leksykografii por. Link, Schaeder 1989).

Metaleksykografia jako dyscyplina naukowa, czyli w postaci znanej obecnie, wykształciła się dopiero w XX w., ale jej historia sięga znacznie dalej. Niełatwo ją prześledzić, ponieważ z powodu dostępności językowej prace na ten temat skupiają się zwykle na leksykografii wybranego języka lub niewielu języków. Słabiej znane pod tym względem są leksykografie z naszej perspektywy odległe. Poza tym opracowania na temat historii leksykografii poszczególnych języków zwykle skupiają się wyłącznie na słownikach. Dość dokładnie poznajemy więc najstarsze, najciekawsze i najważniejsze dzieła leksykograficzne stworzone dla opisu danego języka, ale bardzo rzadko autorzy poświęcają uwagę metaleksykografii. W trzech tomach encyklopedii Wörterbücher Dictionaries - Dictionnaires (HSK 5.1-5.3, 1989-1991) zamieszczonych jest ponad sto artykułów przedstawiających historię leksykografii różnych języków. Historii myśli metaleksykograficznej poświęcono tam mało miejsca. Do wyjątków należy np. Helmut Jachnow (1990), który przedstawiając leksykografię rosyjską, w osobnej części omawia badania metaleksykograficzne z półwiecza poprzedzającego publikację. W czwartym tomie (HSK 5.4, 2013), zawierającym w rozdziałach na temat najnowszej (tj. od 1990 r.) leksykografii poszczególnych języków prawie trzydzieści artykułów, metaleksykografia uwzględniania jest o wiele częściej i obszerniej.

Rekonstruując zalążki metaleksykografii i jej późniejszy rozwój, należy sięgnąć do źródeł różnego typu. Wiele dawnych słowników, np. już w XVII w., zawiera wstępy bardzo cenne pod względem teoretycznym, traktujące o danym słowniku, innych słownikach czy też ogólnie o leksykografii. Wyjątkową wartość teoretyczną i przez to wpływ na późniejsze słowniki mają także niektóre recenzje słownikowe. Swą dość wybiórczą historię metaleksykografii J.F. Hausmann (1989: 75-77)9 rozpoczyna omówieniem właśnie jednej z takich prac - monumentalnej, obejmującej prawie 400 stron recenzji

9 J.F. Hausmann uwzględnia część leksykografii europejskiej, a opisując metaleksykografię XX w., skupia się głównie na Francji i USA. 
pióra Paola Beniego (1612), zawierającej obok krytyki czterech dzieł leksykograficznych opis reguł, które mają pomóc w stworzeniu idealnego słownika. Kolejne ważne źródło stanowią artykuły hasłowe w starszych encyklopediach. Przykładami obszernych, imponujących rozpraw metaleksykograficznych są hasła dictionnaire d'Alemberta (1754) z IV tomu Encyclopédie (Diderot i in. 1751-1780) oraz dictionary z różnych wydań Encyclopaedia Britannica, zwłaszcza z wyd. 9 (Lyons 1877). Pod koniec XIX w. zaczynają pojawiać się w dużych kompendiach z zakresu nauk filologicznych rozdziały poświęcone leksykografii. Samodzielne publikacje o charakterze metaleksykograficznym, np. artykuły w czasopismach i monografie, są rzadkością nawet na początku XX w. Wcześniej ukazują się nieliczne rozprawy (najstarsze dotyczą słowników łacińskich), bibliografie czy teksty programowe związane $\mathrm{z}$ wielkimi przedsięwzięciami słownikowymi (por. Hausmann 1989).

XX w. jest czasem dynamicznego rozwoju metaleksykografii. Powstają prace koncentrujące się początkowo głównie na historii leksykografii, słownikach w dydaktyce języków obcych czy leksykografii dwujęzycznej. Jedną z pierwszych publikacji tematyzujących teorię leksykograficzną jest artykuł L.V. Szczerby (1940). Do rozwoju teorii przyczyniły się także prace F.J. Hausmanna (1977) czy H.-P. Kromanna i in. (1984), a przede wszystkim Wieganda. Tzw. ogólna teoria leksykografii (Allgemeine Theorie der Lexikographie), której pierwsze zarysy powstały w latach 80. ubiegłego wieku (np. Wiegand 1983, 1983a, 1984), rozwijana była przez ponad 30 lat, a jej oddziaływanie wykracza daleko poza niemiecki obszar językowy. Wkład w rozwój leksykografii teoretycznej mają także naukowcy duńscy, którzy opracowali teorię funkcji leksykograficznych (lexicographical function theory) (por. Bergenholtz 1996, 1998; Tarp 1994, 1995, 2001, 2008; Bergenholtz, Tarp 2002, 2003), a na gruncie polskim Bogusławski (1988, 1988a), zajmujący się m.in. semantyką w ogólnym słowniku jednojęzycznym i wskazaniami dotyczącymi leksykografii dwujęzycznej.

Dorobek metaleksykografii znacząco się powiększył w ciągu kilku ostatnich dziesięcioleci ${ }^{10}$. Obecnie wyróżnia się w jej obrębie cztery działy:

- systematyczne badanie słowników,

- historyczne badanie słowników,

- krytyczne badanie słowników,

- badanie użycia słowników.

Obiektem systematycznego badania słowników są procesy leksykograficzne - metody, etapy, cechy poszczególnych składowych - oraz publikacje leksykograficzne jako produkty tych procesów. Analizowane są struktury słownikowe, m.in. megastruktura, makrostruktura, struktura odsyłaczy (mediostruktura), zewnętrzne i wewnętrzne

${ }^{10}$ Publikacje metaleksykograficzne są zbyt liczne, żeby wzmiankować tutaj chociażby te najważniejsze, poza tym celem artykułu nie jest przedstawienie reprezentatywnego zestawienia bibliograficznego, por. Wiegand (2006-2015). Z nowszych publikacji z każdego działu metaleksykografii można wymienić Jesenšek, Enčeva (2018) - systematyczne badanie słowników, Lobenstein-Reichmann/Müller (2016), McConchie,Tyrkkö (2018) - historyczne badanie słowników, Bielińska, Schierholz (2017) - krytyczne badanie słowników oraz Müller-Spitzer (2014) - badanie użycia słowników. 
struktury dostępu, struktura tematyczno-rematyczna, ścieżki koherencyjne. Badane są poszczególne teksty słownikowe - artykuły hasłowe, ich budowa i typy, ale i wszelkie teksty zewnętrzne (meta- i parateksty). Ten dział metaleksykografii obejmuje także problematykę związaną z typologią słowników, czyli takie zagadnienia jak kryteria i metody klasyfikacji słowników, typy i podtypy słowników oraz właściwości słowników poszczególnych rodzajów.

Historyczne badanie słowników skupia się na różnorakich aspektach związanych ogólnie z rozwojem leksykografii światowej oraz z powstawaniem i ewoluowaniem poszczególnych tradycji leksykograficznych. Analizowana jest historia słowników różnych typów, warunki, w jakich powstawały, i cele, dla których były sporządzane, badany jest wpływ jednych słowników na inne i na rozwój leksykografii danego języka, zmiany leksykografii w różnych epokach historycznych, wpływ słowników na rozwój kulturalny, społeczny i naukowy, a także wpływ warunków politycznych, kulturalnych, gospodarczych etc. na rozwój leksykografii.

Do zadań krytycznego badania słowników należy stworzenie teorii krytyki leksykograficznej oraz ogólnych zasad naukowej oceny publikacji leksykograficznych. Prace z tego obszaru koncentrują się m.in. na wypracowaniu metod i kryteriów ewaluacji słowników różnych typów, standardów umożliwiających opracowanie testów słownikowych, na ocenie, najczęściej w formie recenzji naukowej, jednej lub wielu właściwości wybranego słownika, czasem w porównaniu z innymi słownikami, oraz na analizie samych recenzji słownikowych, naukowych, ale także dziennikarskich.

Badanie użycia słowników to najmłodszy dział metaleksykografii, który ostatnio dzięki coraz lepszym możliwościom pozyskiwania danych szybko się rozwija. W centrum zainteresowań badaczy znajdują się następujące kwestie: Kto używa słownika, w jakich sytuacjach, z jakiego powodu, w jakim celu, z jakim rezultatem? Czy użytkownik posiada odpowiednie umiejętności? Jakie kompetencje są najważniejsze? Jakie potrzeby mają użytkownicy? Jak przebiegają konsultacje słownikowe różnego rodzaju? Badania skupiają się - o czym świadczy tematyka publikacji z tego zakresu - na zachowaniach szerokiej grupy użytkowników, często uczących się języka opisywanego w słowniku jako obcego, a nie np. na zawodowych tłumaczach bądź specjalistach korzystających ze słowników naukowych. Dane pozyskuje się dzięki ankietom, wywiadom, protokołom sporządzanym w trakcie konsultacji słownikowych przez badanych lub przez obserwatorów, testom sprawdzającym kompetencje użytkowników, a w przypadku badania użycia słowników elektronicznych, co w ostatnich latach jest bardzo częste, wykorzystuje się także okulografię i logi (ang. log files). Ogólnym celem tego działu metaleksykografii jest rozwinięcie metodologii badań empirycznych, opracowanie typologii użytkowników, konsultacji słownikowych i sytuacji użycia słowników. Wiedza zdobyta dzięki tym badaniom ma się przyczynić do podniesienia jakości, czyli także użyteczności, publikacji leksykograficznych.

Jakkolwiek przechodzenie od mediów drukowanych do cyfrowych odcisnęło już bardzo wyraźne piętno na leksykografii praktycznej - słowników elektronicznych, w tym internetowych, powstało już bardzo wiele, zachowania i oczekiwania masowego 
odbiorcy publikacji leksykograficznych są obecnie diametralnie różne od tych sprzed kilkunastu lat, zmieniła się rzeczywistość rynkowa, w której funkcjonują wydawnictwa itd. - to $\mathrm{z}$ całościową oceną wpływu tych przemian na metaleksykografię należy się jeszcze wstrzymać.

4.3. Drugą możliwością interpretacji tytułu Leksykografia jako samodzielna dyscyplina, zasugerowaną we wprowadzeniu do bieżącej części wywodu, jest uznanie leksykografii za dyscyplinę akademicką. I w tym przypadku brakuje jednolitego sprecyzowania, czym jest dyscyplina akademicka. To określenie nie jest synonimem określenia „dyscyplina naukowa”, choć dyscypliny akademickie są do pewnego stopnia z naukowymi tożsame. Dodatkowo zawierają jednak elementy kształcenia zawodowego, obejmującego wiedzę i kompetencje również spoza danej dyscypliny naukowej. Praca leksykografa wymaga oprócz wiedzy metaleksykograficznej opanowania warsztatu oraz znajomości specyfiki danego przedsięwzięcia słownikowego. Atkins, Rundell (2013: 569-571) zaliczają do programu kształcenia leksykografów także zarządzanie projektami leksykograficznymi. Niezbędna jest też wiedza dziedzinowa, np. językoznawcza w przypadku słownika językowego czy medyczna w przypadku leksykonu medycznego.

O ile w wyniku rozważań na temat dyscypliny naukowej taki status został przypisany jedynie metaleksykografii, o tyle za dyscyplinę akademicką należałoby uznać leksykografię pojmowaną całościowo, tj. jako leksykografię teoretyczną i praktyczną. W przypadku studiów leksykograficznych - zwykle są to studia magisterskie, jak np. European Master in Lexicography (EMLex) - studia prowadzone także w Polsce, i/lub doktoranckie (por. Atkins, Rundell 2013: 571, Hartmann 2013a: 597-598) - prowadzonych na uniwersytetach i zakończonych dyplomem, można mówić o leksykografii jako dyscyplinie akademickiej o oficjalnym statusie (por. Wiegand 1998: 119). Poza specjalnymi kierunkami studiów seminaria leksykograficzne prowadzone są w ramach innych dyscyplin akademickich. Programy studiów filologicznych, językoznawczych czy translatorycznych obejmują często kursy z leksykografii (por. listy uczelni w Atkins, Rundell 2013: 571; Hartmann 2001: 160; Wiegand 1998: 121-127). Krótsze kursy czy warsztaty organizowane są także poza uniwersytetami, np. Lexicography MasterClass (do 2012) czy Lexicom (od 2001) (więcej w Atkins, Rundell 2013: 571-572).

Leksykografowie zrzeszają się w licznych stowarzyszeniach - lokalnych (np. Scottish Language Dictionary, wcześniej: Scottish National Dictionary Association, Taiwan Dictionary and Corpus Research Center), krajowych (np. China Lexicographical Association, Indian Lexicographical Society), regionalnych (np. Nordisk Forening for Leksikografi (NFL)) i międzynarodowych. Wiele z nich organizuje cykliczne konferencje. Poza dużymi kongresami stowarzyszeń o zasięgu kontynentalnym - European Association for Lexicography (EURALEX), African Association for Lexicography (AFRILEX), Dictionary Society of North America (DSNA), Asian Association for Lexicography (ASIALEX) i Australasian Association for Lexicography (AUSTRALEX) - odbywają się regularnie mniejsze spotkania, np. konferencje eLex (Electronic lexicography 
in the 21st century; Sintra 2019, Leiden 2017 i in.), coroczne EMLex-Colloquium (Stellenbosch 2018, Santiago de Compostela 2017, Katowice, Sosnowiec 2016 i in.) czy Lexikographisches Kolloquium (Poznań 2018, Maribor 2016, Segedyn 2014 i in.). Wydawane są tomy pokonferencyjne, np. w serii Lexicographica Series Maior, czasopisma, np. Lexicographica. An International Annual for Lexicography, Dictionaries (DSNA), International Journal of Lexicography (EURALEX), Lexicography (ASIALEX), Lexikos (AFRILEX) i LexicoNordica (NFL) i newslettery (dokładniejsze informacje w Atkins, Rundell 2013: 571-572, Hartmann 2013, 2013a: 598-600, 2001: 153-155).

\section{Podsumowanie}

Wśród najważniejszych aspektów poruszanych w dyskusjach na temat, czym jest leksykografia, jaka jest jej natura i status, nie ma takiego, co do którego badacze byliby jednomyślni. Nie ma zgodności stanowisk, jeśli chodzi o przypisanie leksykografii wymiaru praktycznego i teoretycznego. Niektórzy widzą w leksykografii jedynie działalność praktyczną, inni definiują ją jako naukę, a część uważa, że leksykografia obejmuje komponent praktyczny i teoretyczny, co najlepiej oddaje jej istotę. Kolejne różnice uwidaczniają się, gdy dokładniej przeanalizuje się sposób pojmowania praktyki i - przede wszystkim - teorii. Teoria leksykograficzna bywa redukowana do nauki o metodach zestawiania słowników, czyli do teoretycznych podstaw praktyki, bywa też mylnie utożsamiana z teorią lingwistyczną bądź do niej zaliczana.

Kwestią bodaj najbardziej interesującą językoznawców jest stosunek leksykografii a właściwie jedynie jej części: leksykografii językowej - do językoznawstwa. Jednym z celów powyższego wywodu było wykazanie, iż opinia, że leksykografia jest działem językoznawstwa czy językoznawstwa stosowanego, subdyscypliną leksykologii lub leksykologią stosowaną, powinna zostać mimo swego rozpowszechnienia i zakorzenienia w literaturze przedmiotu zrewidowana. Statusu leksykografii, nie tylko językowej, nie powinno się uzależniać od przedmiotu opisu leksykograficznego w poszczególnych słownikach. Nie przesądza on bowiem o przynależności dyscyplinowej. Konieczne jest także rozróżnienie płaszczyzny leksykograficznej i językoznawczej w pracy leksykografa, zarówno praktyka, jak i naukowca, oraz uwzględnienie faktu, że leksykografia i językoznawstwo mają inne obiekty badań (słowniki lub ogólniej: publikacje leksykograficzne vs język), co wyklucza traktowanie tej pierwszej dyscypliny jako część drugiej.

Podzielane tu stanowisko, że leksykografia jest samodzielną dyscypliną, także wymagało przedyskutowania, gdyż nawet między pracami badaczy o zbliżonych poglądach występują różnice.

Za odrębną dyscyplinę naukową należy uznać metaleksykografię, której historia i działy zostały tu przedstawione skrótowo, ale chyba wystarczająco dokładnie, aby wykazać, że po pierwsze spełnia kryteria, na podstawie których można uznać ją za dyscyplinę naukową, a po drugie, że badania leksykograficzne nie mają charakteru lingwistycznego. Mimo iż wśród zajmujących się leksykografią większość stanowią naukowcy 
o wykształceniu językoznawczym, nie powinno to skłaniać do postawienia znaku równości między leksykografem a językoznawcą. Badacze ci, zajmując się leksykografią, poszerzyli swą aktywność naukową o drugą dyscyplinę. Takie podejście jest konieczne w przypadku leksykografii językowej, wymagającej znajomości metaleksykografii oraz językoznawstwa. Za dyscyplinę akademicką można natomiast uznać leksykografię pojętą całościowo, nie tylko jej komponent teoretyczny. Leksykografia funkcjonuje jako kierunek studiów na uniwersytetach, leksykografowie mają swoje stowarzyszenia, konferencje, serie wydawnicze i czasopisma.

Określenie, czym dany obszar ludzkiej aktywności jest, a czym nie jest, ma w przypadku leksykografii szczególne znaczenie, ponieważ jest ona powiązana z wieloma dyscyplinami, a wysoce interdyscyplinarny charakter ma zarówno leksykografia praktyczna - w słownikach i encyklopediach została opisana większość gałęzi wiedzy i działalności człowieka - jak i teoretyczna. Leksykografia jest zależna od dyscyplin związanych z obszarem, z którego pochodzi przedmiot opisu leksykograficznego, czyli np. od językoznawstwa, biologii czy historii, ale także od innych nauk, z których wyników i metod korzysta, np. informatyki, socjologii czy informatologii. Ważne jest zatem ustalenie statusu takiej dyscypliny, wytyczenie jej granic i oddzielenie jej tym samym od dyscyplin sąsiednich.

\section{Bibliografia}

\subsection{Słowniki językowe (ogólne)}

CALDT: Cambridge Advanced Learner's Dictionary \& Thesaurus [wersja online z portalu Cambridge Dictionary: https://dictionary.cambridge.org/dictionary/english (14.09.2018)].

COBUILD: COBUILD Advanced English Dictionary [wersja online z portalu Collins Dictionary: https://www.collinsdictionary.com/dictionary/english/ (dostęp: 14.09.2018)].

Collins: Collins English Dictionary [wersja online z portalu Collins Dictionary: https:// www.collinsdictionary.com/dictionary/english/ (dostęp: 14.09.2018)].

D10: Duden. Das große Wörterbuch der deutschen Sprache in 10 Bänden, 1999, red. W. Scholze-Stubenrecht $i$ in., Mannheim i in.

D6: Duden. Das große Wörterbuch der deutschen Sprache in 6 Bänden, 1976-1981, red. G. Drosdowski i in., Mannheim.

DUW1983: Duden. Deutsches Universalwörterbuch, 1983, red. G. Drosdowski i in., Mannheim.

DUW2003: Duden. Deutsches Universalwörterbuch, 2003, red. K. Kunkel-Razum, W. Scholze-Stubenrecht, M. Wermke, Mannheim.

HDG: Handwörterbuch der deutschen Gegenwartssprache, 1984, red. G. Kempcke, Berlin. ISJP: Inny słownik języka polskiego, 2000, red. M. Bańko, Warszawa.

LDOCE: Longman Dictionary of Contemporary English. Third Edition with new words supplement, 2001, red. D. Summers, Harlow $i$ in. 
Macmillan: Macmillan Dictionary [wersja online z portalu Macmillan Dictionary: https:// www.macmillandictionary.com (dostęp: 14.09.2018)].

OEDshort: The New Shorter Oxford English Dictionary on Historical Principles, 1993, red. L. Brown, Oxford.

ODE: Oxford Dictionary of English, 2010, red. C. Soanes, A. Stevenson, Oxford [eBook].

PSWP: Praktyczny słownik współczesnej polszczyzny, 1994-2005, red. H. Zgółkowa, Poznań.

SJPDor: Słownik języka polskiego, 1958-1969, red. W. Doroszewski, Warszawa. SJPSz: Słownik języka polskiego, 1978-1981, red. M. Szymczak, Warszawa.

słownik Arcta: Słownik ilustrowany języka polskiego, 1929, M. Arct, Warszawa.

słownik warszawski: Słownik języka polskiego, 1900-1927, red. J. Karłowicz, A. Kryński, W. Niedźwiecki, Warszawa.

słownik wileński: Słownik języka polskiego, 1861, A. Zdanowicz i in., Wilno.

Ullstein-LdS: Ullstein Lexikon der deutschen Sprache. Wörterbuch für Rechtschreibung, Silbentrennung, Aussprache, Bedeutungen, Synonyme, Phraseologie, Etymologie, 1969, R. Köster i in., Frankfurt a. M.

USJP: Uniwersalny słownik języka polskiego, 2008, red. S. Dubisz, Warszawa [wersja elektroniczna].

Wahrig: Deutsches Wörterbuch, 1986, red. G. Wahrig i in., München.

WDG: Wörterbuch der deutschen Gegenwartssprache, 1964-1977, red. R. Klappenbach, H. Malige-Klappenbach, Berlin [wersja online z portalu Das digitale Wörterbuch der deutschen Sprache: https://www.dwds.de/wb/wdg (dostęp: 14.09.2018)].

Webster: Webster's New World College Dictionary [wersja online z portalu Collins Dictionary: https://www.collinsdictionary.com/dictionary/english/ (dostęp: 14.09.2018)].

WSJP: Język polski. Współczesny słownik języka polskiego, 2007, red. B. Dunaj, Warszawa.

\subsection{Pozostała literatura (leksykony, artykuły, monografie)}

Adamska-Sałaciak A., 2019, Lexicography and Theory: Clearing the Ground, International Journal of Lexicography 32/1, s. 1-19.

d'Alembert J. le Rond, 1754, Dictionnaire, [w:] Encyclopédie ou Dictionnaire raisonné des sciences, des arts et métiers (1751-1780), t. 4, red. D. Diderot i in., Paris, s. 958-969.

Atkins B.T.S., Rundell M., 2008, The Oxford Guide to Practical Lexicography, Oxford.

Atkins B.T.S., Rundell M., 2013, Lexicographic training: An overview, [w:] HSK 5.4, s. 569-574.

Bahr J., 1978, Ist Lexikographie eine Wissenschaft? Bemerkungen zu einer Tagung, Zeitschrift für germanistische Linguistik 6, s. 97-98.

Bakos F., 1983, Gegenseitige Bedingungen von Lexikologie und Lexikographie, [w:] Die Lexikographie von heute und das Wörterbuch von morgen. Analysen Probleme - Vorschläge, red. J. Schildt, D. Viehweger, Berlin, s. 128-140. 
Bańko M., 2001, Z pogranicza leksykografii i językoznawstwa, Warszawa.

Béjoint H., 2010, The Lexicography of English, Oxford.

Bergenholtz H., 1995, Wodurch unterscheidet sich Fachlexikographie von Terminographie?, Lexicographica 11, s. 50-59.

Bergenholtz H., 1996, Grundfragen der Fachlexikographie, [w:] Euralex '96. Proceedings

I-II. Papers submitted to the Seventh EURALEX International Congress on

Lexicography in Göteborg, red. M. Gellerstam i in., Göteborg, s. 731-758.

Bergenholtz H., 1998, Das Schlaue Buch. Vermittlung von Informationen für textbezogene und textunabhängige Fragestellungen, [w:] Symposium on Lexicography VIII. Proceedings of the Eighth International Symposium on Lexicography May $2-5,1996$ at the University of Copenhagen, red. A. Zettersten i in., Tübingen, s. 93-110.

Bergenholtz H., Gouws R., 2012, What is Lexicography?, Lexikos 22, s. 31-42.

Bergenholtz H., Kaufmann U., 1997, Terminography and Lexicography. A Critical

Survey of Dictionaries from a Single Specialised Field, Hermes. Journal of

Linguistics 18, s. 91-125.

Bergenholtz H., Tarp S., 2002, Die moderne lexikographische Funktionslehre.

Diskussionsbeitrag zu neuen und alten Paradigmen, die Wörterbücher als

Gebrauchsgegenstände verstehen, Lexicographica 18, s. 253-263.

Bergenholtz H., Tarp S., 2003, Two opposing theories: On H.E. Wiegand's recent discovery of lexicographic functions, Hermes. Journal of Linguistics 31, s. 171-196.

Bielińska M., 2014, Methoden der Übersetzungswissenschaft und der zweisprachigen Lexikographie, Lexicographica 30, s. 213-246.

Bielińska M. (artykuł w druku): Kontroversen um lexikographische Theorie.

Bielińska M. (w przygotowaniu): Leksykografia. Podstawowe pojęcia (roboczy tytuł leksykonu).

Bielińska M., Schierholz S.J., red., 2017, Wörterbuchkritik - Dictionary Criticism, Berlin i in.

BLS: Lexikon der Sprachwissenschaft, 1990, H. Bußmann, Stuttgart.

Bobrowski I., 1998, Zaproszenie do językoznawstwa, Kraków.

Bogaards P., 1994, Tuning the dictionary to the skills of intermediate learners, [w:] Wörterbücher und ihre Benutzer [=Fremdsprachen Lehren und Lernen 23], red.

G. Henrici, E. Zöfgen, Tübingen, s. 192-205.

Bogusławski A., 1988, Język w słowniku. Desiderata semantyczne do wielkiego słownika polszczyzny, Wrocław $i$ in.

Bogusławski A., 1988a, Dwujęzyczny słownik ogólny. Projekt instrukcji z komentarzami, [w:] Studia z polskiej leksykografii współczesnej, red. Z. Saloni, Wrocław i in., s. 19-65.

Bondzio W. i in., 1980, Einführung in die Grundfragen der Sprachwissenschaft, Leipzig. Caie G.D. i in., red., 2006, The Power of Words: Essays in Lexicography, Lexicology and Semantics, Amsterdam.

Czochralski J., 1981, Zur theoretischen und praktischen Lexikographie, Kwartalnik Neofilologiczny 28, s. 167-180. 
DLP: Diccionario de lexicografía práctica, 1995, J. Martínez de Sousa, Barcelona.

DoL: Dictionary of Lexicography, 2001, R.R.K. Hartmann, G. James, London i in.

EJO: Encyklopedia językoznawstwa ogólnego, ${ }^{2} 1999 / 1993$, red. K. Polański, Wrocław $i$ in.

EJP: Encyklopedia języka polskiego, ${ }^{3} 1999 / 1978$, red. S. Urbańczyk, M. Kucała, Wrocław $i$ in.

Filipec J., 1994, Lexicology and Lexicography: Development and State of the Research, [w:] The Prague School of Structural and Functional Linguistics: A Short Introduction, red. Ph.A. Luelsdorff, Amsterdam, s. 163-183 .

Geeraerts D., 1987, Types of Semantic Information in Dictionaries, [w:] A Spectrum of Lexicography. Papers from AILA, Brussels 1984, red. R. Ilson, Amsterdam, s. $1-10$.

Grochowski M., 1982, Zarys leksykologii i leksykografii. Zagadnienia synchroniczne, Toruń.

Grochowski M., 2004, Informacja semantyczna w słownikach popularnych i naukowych. Postulaty metodologiczne, Poradnik Językowy 9, s. 8-18.

Hanks P., 1979, To what extent does a dictionary definition define?, [w:] Dictionaries and Their Users. Papers from the 1978 B.A. A.L. Seminar on Lexicography, red. R.R.K. Hartmann, Exeter, s. 32-38.

Hartmann R.R.K., 2013, Lexicographic associations, [w:] HSK 5.4, s. 580-586.

Hartmann R.R.K., 2013a, Aids in metalexicographic research, [w:] HSK 5.4, s. 596-611. Hartmann R.R.K., 2001, Teaching and Researching Lexicography, Harlow i in.

Hausmann F.J., 1977, Einführung in die Benutzung der neufranzösischen Wörterbücher, Tübingen.

Hausmann F.J., 1985, Lexikographie, [w:] Handbuch der Lexikologie, red. Ch. Schwarze, D. Wunderlich, Königstein/Ts., s. 371-411.

Hausmann F.J., 1989, Kleine Weltgeschichte der Metalexikographie, [w:] Wörterbücher in der Diskussion. Vorträge aus dem Heidelberger Lexikographischen Kolloquium, red. H.E. Wiegand, Tübingen, s. 75-109.

Henne H., 1972, Semantik und Lexikographie. Untersuchungen zur lexikalischen Kodifikation der deutschen Sprache, Berlin i in.

Henne H., 1980, Lexikographie, [w:] Lexikon der Germanistischen Linguistik, red. H.P. Althaus, H. Henne, H.E. Wiegand, t. 4, Tübingen, s. 778-787.

Householder F.W., 1962, Summary Report, [w:] Problems in lexicography, red. F.W. Householder, S. Saporta, Bloomington, s. 279-282.

HSK 5.1-5.3: Hausmann F.J., Reichmann O., Wiegand H.E., Zgusta L., red., 1989-1991, Wörterbücher - Dictionaries - Dictionnaires. Ein internationales Handbuch zur Lexikographie. t. 1-3. Berlin i in.

HSK 5.4: Gouws R., Heid U., Schweickard W., Wiegand, H.E., red., 2013, Dictionaries. An International Encyclopedia of Lexicography. Supplementary Volume: Recent Developments with Fokus on Electronic and Computational Lexicography, Berlin i in. 
Iskos A., Lenkowa A., ${ }^{3}$ 1970/1960, Deutsche Lexikologie für pädagogische Hochschulen und Fremdsprachenfakultäten, Leningrad.

Jachnow H., 1990, Russische Lexikographie, [w:] HSK 5.2, s. 2309-2329.

Jesenšek V., Enčeva M., red., 2018, Wörterbuchstrukturen zwischen Theorie und Praxis, Berlin $i$ in.

Kania S., Tokarski J., 1984, Zarys leksykologii i leksykografii polskiej, Warszawa.

Kempcke G., 1982, Lexikologie, lexikographische Theorie und lexikographische Praxis, [w:] Wortschatzforschung heute. Aktuelle Probleme der Lexikologie und Lexikographie, red. E. Agricola i in., Leipzig, s. 42-61.

Kromann H.-P., Riiber T., Rosbach P., 1984, Überlegungen zu Grundfragen der zweisprachigen Lexikographie, [w:] Studien zur neuhochdeutschen Lexikographie V, red. H.E. Wiegand, Hildesheim i in., s. 159-238.

Kučera A. i in., 1985, Introduction, Lexicographica 1, s. IX-X.

Kühn I., 1994, Lexikologie. Eine Einführung, Tübingen.

Laskowski R., 1999, Leksykografia, [w:] EJP, s. 209.

LDBT: Lexicography. A Dictionary of Basic Terminology, 1998, I. Burkhanov, Rzeszów. Lewicki A.M., 1999, Leksykografia, [w:] EJO, s. 331-334.

Lewkowskaja X.A., 1968, Lexikologie der deutschen Gegenwartssprache, Moskau.

Link, E. Schaeder B., 1989, Fachsprache der Lexikographie, [w:] HSK 5.1, s. 312-322.

Lobenstein-Reichmann A., Müller P.O., red., 2016, Historische Lexikographie zwischen Tradition und Innovation, Berlin $i$ in.

Lyons P.A., 1877, Dictionary, [w:] Encyclopaedia Britannica, ${ }^{9} 1875-1889$, t. 7, red.

S.T. Baynes, W. Robertson Smith, London, s. 179-193.

McConchie R., Tyrkkö J., 2018, Historical Dictionaries in their Paratextual Context, Berlin i in.

Meier H.H., 2003, Lexicography as Applied Linguistics, [w:] Lexicography. Critical

Concepts III, red. R.R.K. Hartmann, London i in., s. 307-318.

Miodunka W., 1989, Podstawy leksykologii i leksykografii, Warszawa.

Miodunka W., 1995, [rec.] T. Piotrowski, Z zagadnień leksykografii, Warszawa 1994, Poradnik Językowy 1, s. 70-74.

MLS: Metzler Lexikon Sprache, 2000, red. H. Glück, Stuttgart i in.

Müller-Spitzer C., red., 2014, Using Online Dictionaries, Berlin i in.

New Approaches to Specialized English Lexicology and Lexicography, 2011, red.

I. Balteiro, Newcastle upon Tyne.

NLO: Nordisk leksikografisk ordbok, 1997, H. Bergenholtz, I. Cantell i in., Oslo.

Otwinowska B., 1998, Słowniki, [w:] Słownik literatury staropolskiej. Średniowiecze, renesans, barok, red. T. Michałowska i in., Wrocław, s. 879-885.

Piotrowski T., 1994, Z zagadnień leksykografii, Warszawa.

Piotrowski T., 2001, Zrozumieć leksykografię, Warszawa.

Piotrowski T., 2013, A Theory of Lexicography - Is There One?, [w:]. The Bloomsbury

Companion to Lexicography, red. H. Jackson, London i in., s. 303-320.

PhW: Philosophisches Wörterbuch, 1971, t. 1-2, red. M. Buhr, G. Klaus, Berlin. 
Posner R., 1988, What is an Academic Discipline?, [w:] Gedankenzeichen. Festschrift für Klaus Oehler zum 60. Geburtstag, red. R. Clausen, R. Daube-Schackat, Tübingen, s. 165-185.

Quemada B., 1972, Lexicology and Lexicography, [w:] Current Trends in Linguistics IX: Linguistics in Western Europe, red. Th. Sebeok i in., The Hague, s. 395-475. Quemada B., 1987, Notes sur lexicographie et dictionnairique, Cahiers de lexicologie LI, s. 229-242.

Schaeder B., 1981, Lexikographie als Praxis und Theorie, Tübingen.

Schaeder B., 1987, Germanistische Lexikographie, Tübingen.

Schaeder B., 2000, Lexikographie, [w:] MLS, s. 410.

Schippan Th., 1984, Lexikologie der deutschen Gegenwartssprache, Leipzig.

Schippan Th., 1992, Lexikologie der deutschen Gegenwartssprache, Tübingen.

Schlaefer M., 2002, Lexikologie und Lexikographie. Eine Einführung am Beispiel deutscher Wörterbücher, Berlin.

SDJO: Słownik dydaktyki języków obcych, 1997, A. Szulc, Warszawa.

Sinclair J.M., 1984, Lexicography as an Academic Subject, [w:] LEXeter'83 Proceedings. Papers from the International Conference on Lexicography at Exeter, 9-12 September 1983, red. R.R.K. Hartmann, Tübingen, s. 3-12.

Szczerba (1940): Ščerba L.V., 1982, Versuch einer allgemeinen Theorie der Lexikographie, [w:] Aspekte der sowjetrussischen Lexikographie. Übersetzungen, Abstracts, bibliographische Angaben, red. W. Wolski, Tübingen, s. 17-62./Ščerba L.V., 1995, Towards a General Theory of Lexicography, International Journal of Lexicography 8(4), s. 315-350.

Tarp S., 1994, Funktionen in Fachwörterbüchern, [w:] Fachlexikographie. Fachwissen und seine Repräsentation in Wörterbüchern, red. H. Bergenholtz, B. Schaeder, Tübingen, s. 229-246.

Tarp S., 1995, Wörterbuchfunktionen: Utopische und realistische Vorschläge für die bilinguale Lexikographie, [w:] Studien zur zweisprachigen Lexikographie mit Deutsch II, red. H.E. Wiegand, Hildesheim i in., s. 17-51.

Tarp S., 2001, Lexicography and the linguistic concepts of homonymy and polysemy, Lexicographica 17, s. 22-39.

Tarp S., 2008, Lexicography in the Borderland between Knowledge and NonKnowledge. General Lexicographical Theory with Particular Focus on Learner's Lexicography, Tübingen.

Tarp S., 2010, Reflections on the Academic Status of Lexicography, Lexikos 20, s. 450 465.

ten Hacken P., 2009, What is a Dictionary? A View from Chomskyan Linguistics, International Journal of Lexicography 22(4), s. 399-421.

Ttt: Lukszyn J., red., 1998, Tezaurus terminologii translatorycznej, Warszawa.

Urdang L., 1963, Review: Problems in Lexicography. Report of the Conference on Lexicography, Language 39(3), s. 586-594. 
Wiegand H.E., 1983, Überlegungen zu einer Theorie der lexikographischen Sprachbeschreibung, [w:] Symposium on Lexicography, red. K. Hyldgaard-Jensen, A. Zettersten, Hildesheim i in., s. 35-72.

Wiegand H.E., 1983a, Ansätze zu einer Allgemeinen Theorie der Lexikographie, [w:] Die Lexikographie von heute und das Wörterbuch von morgen. Analysen - Probleme Vorschläge, red. J. Schildt, D. Viehweger, Berlin, s. 92-127.

Wiegand H.E., 1984, On the Structure and Contents of a General Theory of Lexicography, [w:] LEXeter'83 Proceedings. Papers from the International Conference on Lexicography at Exeter, 9-12 September 1983, red. R.R.K. Hartmann, Tübingen, s. $13-30$.

Wiegand H.E., 1985, Zum Verhältnis von germanistischer Lexikologie und Lexikographie, [w:] Germanistik. Forschungsstand und Perspektiven. t. 1, red. G. Stötzel, Berlin i in., s. 69-73.

Wiegand H.E., 1989, Der gegenwärtige Status des Lexikographie und ihr Verhältnis zu anderen Disziplinen, [w:] HSK 5.1, s. 246-280.

Wiegand H.E., 1998, Wörterbuchforschung. Untersuchungen zur Wörterbuchbenutzung, zur Theorie, Geschichte, Kritik und Automatisierung der Lexikographie, t. 1, Berlin $i$ in.

Wiegand H.E., 2006-2015, Internationale Bibliographie zur germanistischen Lexikographie und Wörterbuchforschung: mit Berücksichtigung anglistischer, nordistischer, romanistischer, slavistischer und weiterer metalexikographischer Forschungen, t. 1-5, Berlin $\mathrm{i}$ in.

Wiegand H.E., 2013, Lexikographie und Angewandte Linguistik, Zeitschrift für angewandte Linguistik, s. 13-39.

Wierzbicka A., 1985, Lexicography and Conceptual Analysis, Ann Arbor.

WLWF: Wörterbuch zur Lexikographie und Wörterbuchforschung / Dictionary of Lexicography and Dictionary Research, t. 1-2, 2010-2017, H.E. Wiegand $i$ in., Berlin $i$ in.

Wolski W., 1997, Die Fachsprache der Metalexikographie, [w:] Linguistische Theorie und lexikographische Praxis. Symposiumsvortraege. Heidelberg 1996, red. K.-P. Konerding, A. Lehr, Tübingen, s. 219-228.

Wolski W., 2005, Lexikologie und Lexikographie, [w:] Lexikologie. Ein internationales Handbuch zur Natur und Struktur von Wörtern und Wortschätzen/ Lexicology. An international handbook on the nature and structure of words and vocabularies, t. 2, red. A. Cruse, F. Hundsnurscher i in., Berlin i in., s. 1816-1828.

Żmigrodzki P., 2008, Słowo - słownik - rzeczywistość. Z problemów leksykografii i metaleksykografii, Kraków. 


\section{Apendyks}

Poniższe zestawienie zawiera jedynie definicje wykorzystane w powyższym tekście.

7.1. leksykografia/leksykografja - lexicography - Lexikographie - lessicografia - leksikografi

7.1.1. Definicje ze słowników ogólnych

lek•sy•ko•gra•fia [...] Leksykografia to pisanie i wydawanie słowników [...].

- Także ogół słowników danego kraju, języka, okresu itp. [...] (ISJP)

leksykografia [...]jęz. «układanie słowników, nauka o metodach opracowywania słowników» [...] (SJPDor)

leksykografia [...] «gałąź wiedzy zajmująca się metodami i techniką opracowywania słowników; opracowywanie słowników, słownikarstwo» (SJPSz)

Leksykografja [...] układanie słowników; słownikarstwo (słownik Arcta)

Leksykografja [...] pisanie słownika (słownik wileński)

leksykografia $[\ldots]$ jęz.

a) «dział językoznawstwa, nauka o metodach opracowywania słowników»

b) «opracowywanie słowników; słownikarstwo»

c) «ogół słowników danego języka, kraju, okresu itp.» [...] (USJP)

leksykografia [...] 'dział językoznawstwa stosowanego zajmujący się teorią i praktyką opracowywania słowników’ (WSJP)

lexicography [...] the activity or job of writing dictionaries (CALDT)

lexicography [...] Lexicography is the activity or profession of writing dictionaries. (COBUILD)

lexicography $[\ldots]$ the process or profession of writing or compiling dictionaries (Collins)

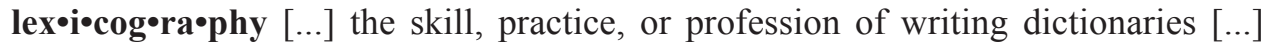
(LDOCE) 
lexicography $[\ldots]$ the activity or occupation of compiling dictionaries [...] (ODE)

lexicography $[\ldots]$ The art or practice of writing dictionaries. (OEDShort)

lexicography $[\ldots]$ the act, process, art, or work of writing or compiling a dictionary or dictionaries (Webster)

Le|xi|ko|gra|phie [...] [Wissenschaft von der] Aufzeichnung u. Erklärung des Wortschatzes in Form eines Wörterbuchs. (D10, D6, DUW1983, DUW2003)

Lexikographie [...] Wissenschaft von der Zusammenstellung und Erklärung des Wortschatzes in Wörterbüchern und Lexika [...] (HDG)

Lexikographie [...] Herstellung, Abfassung eines Lexikons u. die Lehre davon (UllsteinLdS)

Le•xi•ko•gra'phie [...] Lehre von den Wörterbüchern, ihrer Zusammenstellung $u$. Abfassung (Wahrig)

Lexikographie [...] Sprachwiss. Wissenschaft von der Zusammenstellung eines Wörterbuchs, Lexikons (WDG)

\subsubsection{Definicje z leksykonów z zakresu językoznawstwa i leksykografii}

Leksykografia. 1. Tworzenie $\rightarrow$ słowników, słownikarstwo. 2. Nauka, której przedmiotem są słowniki różnych rodzajów (w tym językowe i encyklopedyczne, encyklopedie), uważana za dział językoznawstwa. Przez wiele wieków uprawiana jako zbiór umiejętności praktycznych, uogólnionych niekiedy we wstępach do słowników i encyklopedii, wyodrębniła się jako samodzielna dyscyplina badawcza i teoretyczna w poł. $\mathrm{XX}$ w. [...] (EJO)

Leksykografia jest działem językoznawstwa stosowanego [...], zajmującym się teorią i praktyką zestawiania słowników [...] (EJP)

Leksykografia [...] Dział $\uparrow$ leksykologii stosowanej, zajmujący się teorią i praktyką sporządzania słowników jedno- i więcejjęzycznych. (SDJO)

leksykografia [...] Dyscyplina lingwistyczna badająca słowniki w aspekcie typologicznym $[\ldots](\mathrm{Ttt})$ 
lexicography The professional activity and academic field concerned with DICTIONARIES and other REFERENCE WORKS. It has two basic divisions: lexicographic practice, or DICTIONARY-MAKING, and lexicographic theory, or DICTIONARY RESEARCH [...] (DoL)

LEXICOGRAPHY [...] All experst will probably agree that the term „lexicography” denotes both actual dictionary-making, and lexicographic research, i.e. the science of the making of dictionaries [...] (LDBT) $)^{11}$

Lexikographie [...] Vorgang, Ergebnis und Methode der Anfertigung von Wörterbüchern. Einerseits auf der Basis der $\rightarrow$ Lexikologie, die die theoretischen Grundlagen und Materialien für die lexikographische Kodierung bereitstellt, andererseits auf der Basis von Sachzwängen wie Verkäuflichkeit, Benutzerfreundlichkeit etc. entwickelt die L. die für die Dokumentation des Wortschatzes einer Sprache, eines Dialekts oder Sachgebiets erforderlichen Prinzipien [...] (BLS)

Lexikographie [...] Wiss. Praxis des Konzipierens, Verfassens, Redigierens, Herausgebens, Überarbeitens von Wbb. [...] Die L. ist Forschungsgegenstand der Metalexikographie bzw. $\uparrow$ Wörterbuchforschung, die u.a. auch dazu beitragen möchte, daß die L. ein wiss. Fundament enthält. (MLS)

leksikografi utarbeiding av ordbøker og undersøkelse og utvikling av teorier om ordbøkers tilkomst, egenskaper, formål og bruk [...] (NLO)

\subsection{Lexikograph}

Le•xi•ko'graph [...] Verfasser, Bearbeiter eines Lexikons od. Wörterbuches [...] (Wahrig)

Lexikograph [...] Sprachwiss. Verfasser, Bearbeiter eines Wörterbuchs, Lexikons (WDG)

11 W LDBT nie ma wyodrębnionej definicji. W apendyksie zamieszczono fragment hasła odnoszący się do zagadnienia poruszanego w punkcie 2 . 


\section{3. leksykologia/leksykologja - lexicology - Lexikologie}

\subsubsection{Definicje ze słowników ogólnych}

leksykologia [...] językoznawczy ,nauka o słownictwie obejmująca m.in. analizę pochodzenia, znaczeń i użycia wyrazów; stanowi teoretyczną podstawę leksykografii” (PSWP)

leksykologia [...] jęz. «dział językoznawstwa badający wyrazy pod kątem ich znaczenia i użycia; nauka o słownictwie, teoretyczna, naukowa podstawa leksykografii» (SJPDor)

leksykologia [...] jęz. «dział językoznawstwa, nauka o słownictwie, tj. o zasobie wyrazów i związków wyrazowych, badająca m.in. znaczenie, użycia i pochodzenie wyrazów; stanowi teoretyczną podstawę leksykografii» (SJPSz)

Leksykologja [...] nauka o pochodzeniu, znaczeniu i używaniu wyrazów, słownikarstwo (słownik Arcta)

Leksykologja [...] 1. nauka o układaniu słowników, o stownikach. 2. nauka o znaczeniu i używaniu wyrazów, słownikarstwo, słownikoznawstwo [...] (słownik warszawski)

Leksykologja [...] nauka o słownikach i ich układaniu (słownik wileński)

leksykologia [...] jęz. «dział językoznawstwa, nauka o słownictwie, tj. zasobie wyrazów i związków wyrazowych, badająca m.in. znaczenie, użycia i pochodzenie wyrazów, będąca teoretyczną podstawą leksykografii» (USJP)

lexicology $[\ldots]$ the study of words and their meaning and use (CALDT)

lexicology $[\ldots]$ the study of the overall structure and history of the vocabulary of a language (Collins)

lex•i•col•0•gy [...] technical the study of the meaning and uses of words (LDOCE)

lexicology $[\ldots]$ the study of the form and meaning of words (Macmillan)

lexicology $[\ldots]$ the study of the form, meaning, and behaviour of words $[\ldots]$ (ODE)

lexicology $[\ldots]$ the study of the meanings and origins of words (Webster) 
Le|xi|ko|lo|gie [...] Bereich der Sprachwissenschaft, der sich mit der Erforschung des Wortschatzes (bes. mit der Struktur des Wortschatzes) befasst [u. die theoretischen Grundlagen für die Lexikographie schafft]. (D10, D6)

Le|xi|ko|lo|gie [...] Bereich der Sprachwissenschaft, der sich mit der Erforschung des Wortschatzes (bes. mit der Struktur des Wortschatzes) befasst. (DUW2003)

Lexikologie [...] Wissenschaft, die sich mit der Erforschung des Wortschatzes einer Sprache befaßt (HDG)

Le•xi•ko•lo'gie [...] Lehre vom Wortschatz, seine Erforschung u. Zusammenstellung, Etymologie, Semantik u. Wortbildungslehre [...] (Wahrig)

Lexikologie [...] Sprachwiss. Wissenschaft, die sich mit dem Wortschatz einer Sprache befaßt [...] (WDG)

\subsubsection{Definicje z leksykonów z zakresu językoznawstwa}

Leksykologia [...] Dział językoznawstwa zajmujący się związkami i zależnościami między wyrazami i ich znaczeniami. Wyniki badań leksykalnych wykorzystuje $\uparrow l e k-$ sykografia [...] (SDJO)

Lexikologie [...] Teilbereich der Sprachwiss. bzw. der $\rightarrow$ Semantik, der sich mit der Erforschung und Beschreibung des Wortschatzes beschäftigt [...]. Die Ergebnisse der L. können von der $\rightarrow$ Lexikographie (Technik der Anfertigung von Wörterbüchern) kodifiziert werden, wenngleich die Beziehungen zwischen beiden Bereichen nicht allzu direkt angesetzt werden dürfen. (BLS)

Lexikologie [...] 1. I.w.S. Teildisziplin der Ling., die sich der Erforschung und Beschreibung des $\uparrow$ Lexikons, der Lexik bzw. des $\uparrow$ Wortschatzes widmet. [...] Von den Erkenntnissen der L. profitiert u.a. die $\uparrow$ Lexikographie, die Wortschätze bzw. Wortschatzausschnitte in allgemeinen oder speziellen Wbb. zusammenstellt. [...] (MLS)

\section{4. stownikarstwo}

Słownictwo, Słownikarstwo, umiejętność układania słowników, leksykologia; dział słowników w literaturze; zasób wyrazów w pewnym zakresie, terminologia; cały zasób wyrazów w pewnym języku (słownik Arcta) 
Słownikarstwo, v. Słównikarstwo [...] 1) v. Słownictwo, leksykografja, leksykologja, układanie słowników, nauka, sztuka, praca układania słowników [...] 2) $=s b$. słownikarze, leksykografowie. (słownik wileński)

Słownictwo [...] 1. a. Slownikarstwo = a) sztuka pisania słowników, pisanie słownika, leksykografja, leksykologja. b) dziat stowników w literaturze, dziat prac słownikarskich [...]. 2. zasób wyrazów w danym zakresie, terminologja [...] (słownik warszawski).

\section{STRESZCZENIE}

Słowa kluczowe: leksykografia, praktyka i teoria leksykograficzna, leksykografia jako samodzielna dyscyplina, językoznawstwo, leksykologia.

W artykule przedstawiono różne, często sprzeczne opinie na temat statusu i istoty leksykografii oraz omówiono m.in. następujące zagadnienia: Czy leksykografia to praktyka, teoria czy też jedno i drugie? Czy leksykografia jest częścią lingwistyki, lingwistyki stosowanej, leksykologii, leksykologii stosowanej czy odrębną dyscypliną? Według autorki leksykografię należy rozumieć jako praktykę i teorię. Leksykografia, której przedmiotem badań jest słownik, nie stanowi części językoznawstwa, którego przedmiotem badań jest język. Metaleksykografia powinna być traktowana jako odrębna dyscyplina naukowa, natomiast leksykografia jako całość obejmująca komponent praktyczny i teoretyczny może być traktowana jako dyscyplina akademicka.

\section{SUMMARY}

\section{Status and nature of lexicography. Positions and controversies}

Keywords: lexicography, lexicographical practice and theory, lexicography as independent discipline, linguistics, lexicology.

The article presents different, often contradictory, opinions on the status and nature of lexicography and discusses, among others, the following issues: is lexicography practice, theory or both? Is lexicography a part of linguistics, applied linguistics, a sub-discipline of lexicology or applied lexicology, or a separate discipline? The main aim of the article is to show how lexicography should be understood both as practice and theory, and that lexicography, whose object of study is a dictionary, is not a part of linguistics, whose object of study is language. According to the author, metalexicography should be considered a separate scientific discipline, while lexicography as a whole, i.e. its practical and theoretical components, can be considered an academic discipline. 